\title{
Review \\ Layer-by-Layer Cell Encapsulation for Drug Delivery: The History, Technique Basis, and Applications
}

\author{
Wenyan $\mathrm{Li}^{1,+}\left(\mathbb{C}\right.$, Xuejiao Lei ${ }^{1,+}$, Hua Feng ${ }^{1}$, Bingyun $\mathrm{Li}^{2}{ }^{-}$, Jiming Kong ${ }^{3, *} \mathbb{C}$ and Malcolm Xing ${ }^{4, *}$ \\ 1 Department of Neurosurgery, First Affiliated Hospital, Army Medical University, 30 Gaotanyan Street, \\ Chongqing 400038, China; lwy243@tmmu.edu.cn (W.L.); xuejiaolei@tmmu.edu.cn (X.L.); \\ fenghua@tmmu.edu.cn (H.F.) \\ 2 Department of Orthopaedics, School of Medicine, West Virginia University, Morgantown, WV 26506, USA; \\ bili@hsc.wvu.edu \\ 3 Department of Human Anatomy and Cell Science, University of Manitoba, 745 Bannatyne Avenue, \\ Winnipeg, MB R3E 0J9, Canada \\ 4 Department of Mechanical Engineering, University of Manitoba, 75 Chancellors Circle, \\ Winnipeg, MB R3T 5V6, Canada \\ * Correspondence: jiming.kong@umanitoba.ca (J.K.); malcolm.xing@umanitoba.ca (M.X.) \\ + These authors contributed equally to this work.
}

Citation: Li, W.; Lei, X.; Feng, H.; Li, B.; Kong, J.; Xing, M. Layer-by-Layer Cell Encapsulation for Drug Delivery: The History, Technique Basis, and Applications. Pharmaceutics 2022, 14, 297. https://doi.org/10.3390/ pharmaceutics 14020297

Academic Editors: Thierry Vandamme and Luisa Coderch

Received: 18 November 2021

Accepted: 24 January 2022

Published: 27 January 2022

Publisher's Note: MDPI stays neutral with regard to jurisdictional claims in published maps and institutional affiliations.

Copyright: (C) 2022 by the authors. Licensee MDPI, Basel, Switzerland. This article is an open access article distributed under the terms and conditions of the Creative Commons Attribution (CC BY) license (https:// creativecommons.org/licenses/by/ $4.0 /)$.

\begin{abstract}
The encapsulation of cells with various polyelectrolytes through layer-by-layer (LbL) has become a popular strategy in cellular function engineering. The technique sprang up in 1990s and obtained tremendous advances in multi-functionalized encapsulation of cells in recent years. This review comprehensively summarized the basis and applications in drug delivery by means of LbL cell encapsulation. To begin with, the concept and brief history of LbL and LbL cell encapsulation were introduced. Next, diverse types of materials, including naturally extracted and chemically synthesized, were exhibited, followed by a complicated basis of LbL assembly, such as interactions within multilayers, charge distribution, and films morphology. Furthermore, the review focused on the protective effects against adverse factors, and bioactive payloads incorporation could be realized via LbL cell encapsulation. Additionally, the payload delivery from cell encapsulation system could be adjusted by environment, redox, biological processes, and functional linkers to release payloads in controlled manners. In short, drug delivery via LbL cell encapsulation, which takes advantage of both cell grafts and drug activities, will be of great importance in basic research of cell science and biotherapy for various diseases.
\end{abstract}

Keywords: layer-by-layer; cell encapsulation; cell nanocoating; cell surface engineering; drug delivery

\section{Introduction}

Recent decades have witnessed the rapid development of cell encapsulation. Cell encapsulation, which is a form of cell surface modification, leads to material film coatings on cell membranes. This technique has drawn much attention in various fields, such as cell therapy, cell biosensors, biocatalysts, and so on [1-3]. Further, since it provides an artificial microenvironment surrounding cells, it can also be viewed as a platform for investigating interactions between cells and extracellular matrix (ECM).

Based on the cell number, it can be sorted as an encapsulation of cell mass and single cell [4]. The encapsulation of cell mass is to coat cell group with materials in order to evaluate the cellular function as a whole. On the contrary, single-cell encapsulation endows surface coating via material "shell" on individual cells. Thus, it facilitates the exploration of homogenized influences on single cells and become attractive in recent years [5]. With the progress in single-cell encapsulation, eukaryocytes, especially stem cells, are gradually attempted to serve as the core, and the technique becomes an interdisciplinary field of chemistry, biology, and material science. 
Among the diverse range of methodologies for building up cell encapsulation, layerby-layer (LbL) self-assembly is a well-defined one [6]. The strategy yields the stacking of polyelectrolytes by their opposite charges and enables the building of thin films in a fast, economical, and controllable way [7]. Since the cell membrane is negatively charged, a LbL technique is naturally applicable to establish a permeable, biocompatible, and modifiable capsule in single-cell level, exerting great potentials in various applications.

\section{History of LbL Single-Cell Encapsulation}

The LbL self-assembly technique which leverages electrostatic adsorption was introduced by Decher in early the 1990s [8]. Since then, it has attracted significant attention in a diverse range of fields, for example, chemistry, nano-materials, and biology [9-11]. Among these attempts, cell encapsulation has emerged as a cutting-edge technique (Figure 1).

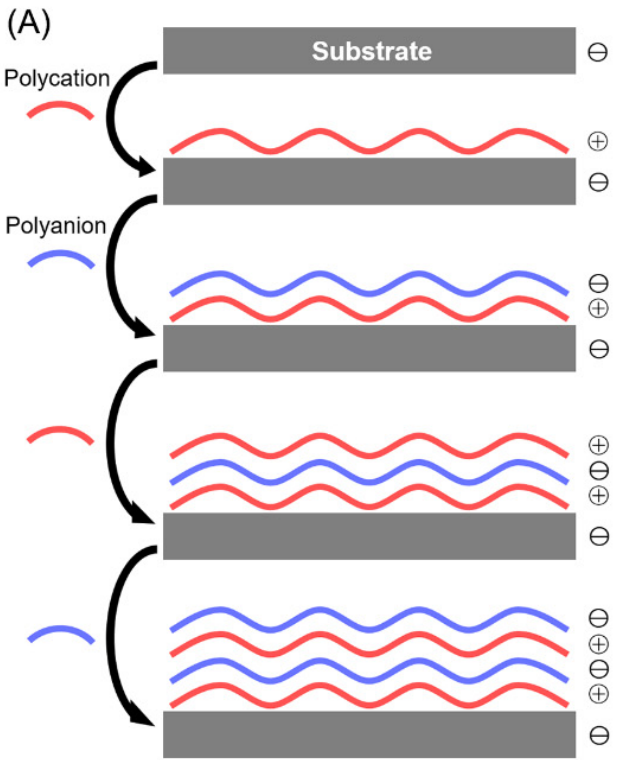

(B)

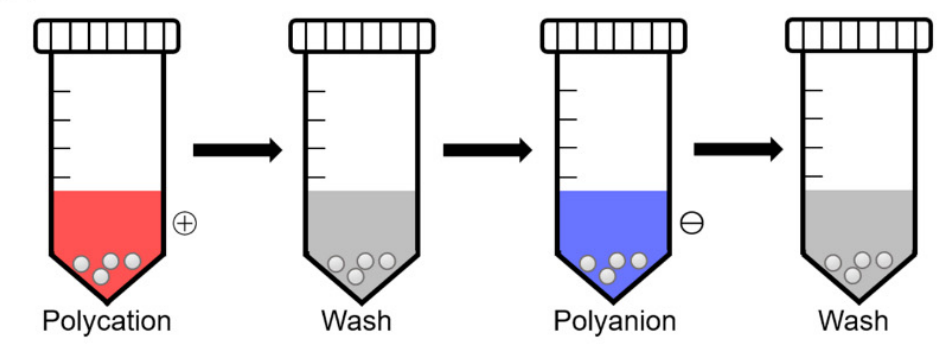

(C)



Figure 1. Scheme of the LbL cell encapsulation. (A) Negatively charged substrate is incubated with polycation and polyanion alternatively to stack polyelectrolyte films on the substrate based on the electrostatic force. (B) Cells in a centrifuge tube are incubated with polycation, followed by centrifuge and washing with buffer solution. Polyanion is then introduced in the same way. (C) Cell surface is modified with multilayers using LbL self-assembly.

In 2000, Möhwald et al. firstly introduced cell encapsulation via LbL. In their research, fixed erythrocytes were encapsulated using poly(allylamine hydrochloride) (PAH) and poly(styrene sulfonate) sodium salt (PSS) [12]. Fixed Escherichia coli (E. coli) was also encapsulated with these polyelectrolyte pairs by Neu et al. [13]. Not long after, people began to encapsulate live cells with LbL. In 2007, Sugunan et al. utilized gold nanoparticles (AuNPs) in the encapsulation of live fungi [14]. These works have evidenced the feasibility of LbL on cells, but they generally regard cells as the encapsulating core and thus overlook the functions. Indeed, these materials are even cytotoxic for mammalian cells with complicated functions $[15,16]$.

Researchers started to pay attention to the cellular function in encapsulation on mammalian cells. Lvov and colleagues coated poly(dimethyldiallylammonium chloride) (PDDA) and PSS on platelets. They proved that the tuning of encapsulation conditions would affect the functions of platelets [17]. Surface characteristics of encapsulated cells, such as roughness and stickiness, were then investigated in a followed study [18]. Further, Diaspro et al. found that proliferation of cells could be affected by coating with PAH and PSS [19]. These early works demonstrated that single-cell encapsulation via LbL technique can impose various influences on cells, such as viability, migration, proliferation, and differentiation, laying the foundation of future applications. 
Investigations into applications of single-cell encapsulation began to arise in 2009, when erythrocytes were protected from immune attack via encapsulation which plays a role in camouflaging [20]. It was also applied to evaluate the nutrient uptake of Bacillus subtilis (B. subtilis) from ECM and the proliferation rate [21]. Since the polyelectrolytes have reactive sites, $\mathrm{Li}$ and Lin loaded growth factors on these materials for cell encapsulation to regulate functions of stem cells and dermal cells [22,23]. Mooney et al. even modified the sensitivity of mesenchymal stem cells to cytokines through encapsulation and grafted them in mice [24]. In 2020, researchers managed to manipulate the ingredient of cell membrane, for example glycan, via click-chemistry to form adjustable encapsulation [25]. It is worth noting that some materials or strategies are inappropriate for mammalian cells due to the effect of cell membrane destruction by some polycations [26]. Therefore, for probing the applications of single-cell encapsulation, proper choice of materials is important.

\section{Biomaterials Employed in LbL Cell Encapsulation}

Materials used in LbL encapsulation can determine the success of single-cell coating to a large extent. Polycations with positive charges have been described as possessing characteristics such as anti-peroxidation, anti-tumor, and anti-inflammation $[27,28]$. Polyanions with negative charges are broadly applied in drug delivery, chemical synthesis, and so on $[29,30]$. Chain structure, electrostatic force, reactive amine groups, active chemical bonds, and nucleophilicity underpin the essential differences between different polyelectrolytes. Based on the existing work, some of these polyelectrolytes are largely used in coating of non-mammalian cells, and some are mainly used in mammalian cells (Table 1). The difference is greatly determined by cytotoxicity and application.

\subsection{Polycations Utilized for Non-Mammalian Cell Coating}

Polycations can either come from natural extraction or chemical synthesis. Some polycations, especially synthetic ones with strong electro-positivity, are usually applied in encapsulation of non-mammalian cells that are protected by their cell wall. Synthetic materials are manufactured in standard processes, so that the functional groups on them are highly consistent. Therefore, the application using synthetic polycations tends to become predictable and controllable [31].

\subsubsection{Polyethylenimine (PEI)}

PEI is by far the mostly used polycationic materials in LbL. It can be synthesized to form a linear or branched structure. By hydrolysis of poly(2-ethyl-2-oxazoline), solid linear PEI can be obtained. For the viscous branched form, polymerization of aziridine is required. Since PEI contains large amount of reactive amino groups, it can be conveniently functionalized. For example, branched PEI was proved to bind DNA to constitute copolymers for enhancing transfection rate [32].

However, the toxicity and non-degradability of PEI have apparently impeded its applications in biomedicine [33]. Amino modification, for instance, disulfide bond crosslinking and acylation [34,35], has been performed to lessen the cytotoxicity. Apart from these complicated procedures, modification of the primary amines with trimethylene carbonate is suggested to be an easy approach [36]. As to the improvement of degradability, researchers found that addition of cleavable bonds to PEI chains could sufficiently aid its breakdown, for example, ester conjugation [37].

Since PEI is such a potent polycation, it can only be used in non-mammalian cell encapsulation. Yeast cells were coated as the core with PEI as the protecting layer by Kozlovskaya et al. It was demonstrated that encapsulation films could be maintained for six days (Figure 2A). This multilayered shell was permeable to nutrients so that cellular functions remained intact [38]. 


\subsection{2. $\mathrm{PAH}$}

According to literature on the subject, poly(allylamine phosphate) can react with hydrochloric acid to give rise to product of PAH. It is hydrophilic since there are a large number of hydrogen bonds within its structure [39]. PAH is popular in cell encapsulation owing to its solubility and relatively weaker electro-positivity. Krol et al. encapsulated yeast cells with PAH in 2005, illustrating the effects of molecule filtration and sheer force resistance (Figure 2B) [40]. Some even incorporated nanotubes with PAH to encapsulate yeasts for stabilizing the coating capsules [41].

\subsubsection{PDDA}

PDDA is produced by polymerization of diallyldimethylammonium chloride to gain varied molecular mass and the procedure requires peroxide as the catalyst [42]. The high density of positive charges on PDDA enables it to be suitable in cell coating. Researchers encapsulated Allochromatium vinosum with PDDA and PSS as the polyelectrolyte pair, demonstrating the metabolism of cells still remained unaffected [43]. Similarly to other synthetic polycations such as PEI, PDDA is not appropriate for surface engineering for mammalian cells because of its cytotoxicity.

\subsection{Polycations Utilized for Mammalian Cell Coating}

As it is well acknowledged, the lack of the protection by cell wall makes mammalian cells more vulnerable than non-mammalian cells in most cases. Therefore, materials applied on cell membrane require additional attentions especially for selection of polycations. Generally, there are only natural polycations and a few synthetic ones being verified as adequate candidates in mammalian cell coating since they are degradable, biocompatible and low-immunogenic [44,45]. Furthermore, chemical modification of the materials is still feasible due to the reactive sites, suggesting the various successful applications [5]. Naturally, these materials are usually applicable for both mammalian and non-mammalian cells.

\subsubsection{Gelatin}

Gelatin is extracted from the natural source collagen. Owing to its biocompatibility, low-immunogenicity, and degradability, gelatin has been broadly applied in biomedicine. Its structure complex consists of 18 amine groups, with lysine and arginine showing positive charges. Gelatin has two subtypes, which are determined by manufacturing methods. Acidic degradation gives rise to type A with the isoelectric point (IEP) from 6.0 to 9.0; basic degradation generates type B with the IEP of 4.7 to 5.4. It is believed that asparagine and glutamine are degraded into carboxyl groups during the reaction, decreasing the IEP of type B gelatin. The Food and Drug Administration (FDA) of the United States has evidenced the safety of gelatin in food industry, which guaranteed its extensive use in fields of material and medicine [46,47]. In most cases, type A gelatin receives more attention since it becomes cationic in a neutral environment, and is able to combine with negatively charged surfaces, which includes the cell membrane. For example, encapsulation of cell line and neural stem cells (NSCs) with gelatin were realized, showing no obvious toxicity (Figure 2C) [22,48].

In some instances, those that require stronger polycation, cationization of gelatin can be performed. A passive way is to reduce the $\mathrm{pH}$ of the medium, resulting in the protonation of amino groups on gelatin. A more common approach is to conjugate ethylenediamine or spermine to gelatin under the catalyzation of 1-ethyl-3-(-3-dimethylaminopropyl) carbodiimide hydrochloride (EDC). As a result, gelatin becomes more cationic and is used for various applications $[49,50]$.

\subsubsection{Cationic Cellulose}

This natural polycation consists of a linear conformation by $\beta-1,4-\mathrm{D}$-glucans. It has been verified to be degradable, hydrophilic, and anti-microbial, therefore cellulose and the derivatives are ideal for therapeutic uses [51]. 
Cationic cellulose is obtained through the etherification of alkylene epoxides and glycidyl ammonium; however, the yield of stable product is challenging. The explanation is due to the poor solubility of cellulose which results from the plentiful hydrogen bonds [52]. Kaldeus et al. managed to esterify methacrylate co-polymers with cellulose composite to be amphiphilic and the mechanical features were greatly improved [53].

In addition to esterification, cellulose can react with hydroxyethyl and hydroxypropyl. The former procedure requires substitution of polyethylene glycol to produce polyquaternium derivatives for enhancing drug delivery [54]. Hydroxypropyl cellulose is synthesized by addition of poly (2-dimethylamino ethylmethacrylate) to form a comb-like structure. It has already been approved by FDA because of its biocompatibility [55].

However, the effect of encapsulation using cellulose is controversial. Singh et al. encapsulated Lactobacillus with cellulose and demonstrated satisfied viability of encapsulated cells [56]. Insulin-secreting cells which are acknowledged as INS1E were shown to be encapsulated with cellulose, and the formed artificial islet-like structure exhibited intact cell survival and sensitivity to glucose [57]. However, in an early study, inflammation was found to be provoked by transplanted cells encapsulated by cellulose [58]. Therefore, basic characteristics of cellulose should be deeply clarified for future application of cellulose encapsulation.

\subsubsection{Polyamidoamine}

As a synthetic polycation, polyamidoamine demonstrates marked features, such as biocompatibility and biodegradability. It is obtained by conjugating bis-acrylamides on the backbone via Michael addition. Since the sidechains of backbone are able to be modified, polyamidoamine is regarded to be versatile.

Traditionally, linear polyamidoamine has been proved to be a competent DNA carrier [59]. To improve the cargo delivery and release, the active sites arranged on backbone can be modified with acetal or ketal for hydrolyzation when $\mathrm{pH}$ decreases [60]. Sometimes, hydrolyzed oligoamines can be functionalized with disulfide bonds via Michael reaction. The active disulfide bonds would endow polyamidoamine with better biocompatibility and higher efficiency in gene transfection $[61,62]$.

In addition to DNA delivery, polyamidoamine is well-known in encapsulation of mammalian cells. The phosphine-conjugated polyamidoamine exhibits attenuated toxicity and, thus, the coating on islets does not interfere cell functions. Furthermore, the encapsulation structure demonstrates protective effects for islets against immune responses (Figure 2D) [63].

\subsubsection{Chitosan}

Chitosan is extracted from shells of crustaceans. There are $\mathrm{N}$-acetylglucosamine and D-glucosamine in its constitution with varied ratios, length, and arrangement. It also has a pKa of 6.0 to 6.5, which is approximately weak acidic under neutral environment, implying potentials in biomedicine studies [64].

When $\mathrm{pH}$ is adjusted to lower than 6.0, chitosan gains higher density of charges to be cationic with increased toxicity. However, when the environmental $\mathrm{pH}$ becomes neutral, solubility of chitosan is lowered to generate suspending aggregates. Some people tried to adjust acetylation and molecular mass to alter the electric charges. Owing to its natural source and cationic charges, chitosan is broadly applied to bind with anionic substances, including the cell membrane [65]. Nonetheless, when applied in biomedicine, the low solubility is a remarkable flaw since neutral $\mathrm{pH}$ is required in most occasions. Some demonstrated that chitosan swollen distinctly in aqueous condition to cause burst release of carried drugs [66].

Fortunately, chitosan can be chemically modified to cope with these difficulties. It has been verified that each chitosan unit consists of one reactive amino group and two reactive hydroxyl groups. By means of amino alkalinization and side chain modification, features such as amine protection can be introduced without the impact on the initial characteristics, 
because the process is not affecting the $\mathrm{pH}$ [67]. In addition, solubility of chitosan in solutions with a wide range of $\mathrm{pH}$ value can either be enhanced. Further, viscidity is suggested to be in direct proportion with the extent of alkalinization, benefiting the incorporation of chitosan with other molecules. Specifically, the direct way of alkalinization is to react methyl iodide with chitosan under alkaline environment, with trimethyl chitosan chloride as the most frequently applied form [68,69]. Additionally, there are other methods of chitosan modification. For example, quaternary ammonium of chitosan with the feature of bacteria resistance was fabricated by Jia et al. [70]. Chitosan was also coupled with folate in varied ratios under catalyzation of EDC for delivering chemotherapeutic agents [71]. Alternatively, glycidyl-trimethyl-ammonium chloride was crosslinked with chitosan to generate $\mathrm{N}$-((2-Hydroxy-3-trimethylammonium) propyl) chitosan chloride which presented ideal solubility and permeability under neutral condition in the presence of the tight junctions within the molecules [72]. Meanwhile, conjugation of poly-L-lysine (PLL) will benefit chitosan with higher positive charges, reduced toxicity and enhanced transfection rates even when compared with PEI [73].

In cell encapsulation, chitosan has been widely used in multiple cell types including mesenchymal stem cells (MSCs) [74,75]. In spite of its mechanical instability, chitosan was explored to encapsulate islets together with alginate as grafts in diabetes animals (Figure 2E) [76]. Zhu et al. improved the stability in cell encapsulation by applying $\mathrm{N}$-acetylated chitosan, but cytotoxicity increased accordingly [77]. In short, selection of chitosan derivatives needs special carefulness.

\subsubsection{Poly-L-lysine (PLL)}

PLL which consists of vast amount of primary amino groups is a commonly used synthetic polycation. Via electrostatic force, PLL can be easily coupled with negatively charged substances post protonation. In synthesis, each primary amine protects one lysine monomer, converting into cyclic anhydride which then undergoes a ring-open process to yield PLL. As such, constitution of PLL can be altered simply by tuning ratios of the initiator and lysine [78].

In LbL technique, PLL has been popular in establishing polyelectrolyte films. With a $\mathrm{pH}$ value of 7.0, primary amines of PLL can undergo partial protonation and render PLL the ability to buffer from $\mathrm{pH} 5.7$ to 7.7 . It is notable that modification of molecular weight by adjusting amine groups is of huge influence since the PLL with a high molecular weight exhibits significant cytotoxicity, and that with a lower one showed alleviated toxicity but increased instability $[79,80]$.

To deal with these obstacles, people produced branched functionalized derivatives. For instance, enhanced ability of buffering and decreased deposition can be realized by PEG addition. Additionally, bioactive regulators, such as the artery wall binding peptide, were demonstrated to be introduced to PEG-PLL, through the crosslinking of cysteine [81]. Moreover, drug delivery in a tissue-targeting manner is applicable with chemically modified PLL. Lactic acid incorporation on Doxorubicin-loading PLL was proved to assist the targeting to liver tissue. Through the interaction of JL1, leukemia cells were proved to be targeted [82-84].

To reduce the toxicity of PLL, its dendrimers are usually applied. Initially, by crosslinking with lysine and benzhydrylamine, researchers obtained intermediate product to be bidirectional asymmetric. The lysine derivative can be activated via acid-triggered deprotonation and then generate PLL dendrimer [85]. Afterwards, fabrication of dendrimers is largely processed under alkaline conditions. For example, researchers managed to obtain PLL derivatives with reduced toxicity as well as higher chargers via coupling of arginine, succinimyldipropyldiamine and lysine under alkaline environment [86].

At the same time, PLL has been broadly used in LbL coating for mammalian cells. It was applied with hyaluronic acid (HA) in the LbL encapsulation of MSCs. These materials form a multilayered shell with a thickness of 6.0 to $9.0 \mathrm{~nm}$, exhibiting no adverse effects on cell morphology and survival (Figure 2F) [87]. In another study, Wilson and colleagues 
linked PEG on PLL backbone to attenuate toxicity. It demonstrates that the PEG-conjugated polymer could be used in islets encapsulation without interference of normal functions. In the animal model of diabetes, PEG-PLL-coated islets were proved to be favorable after transplantation [88].
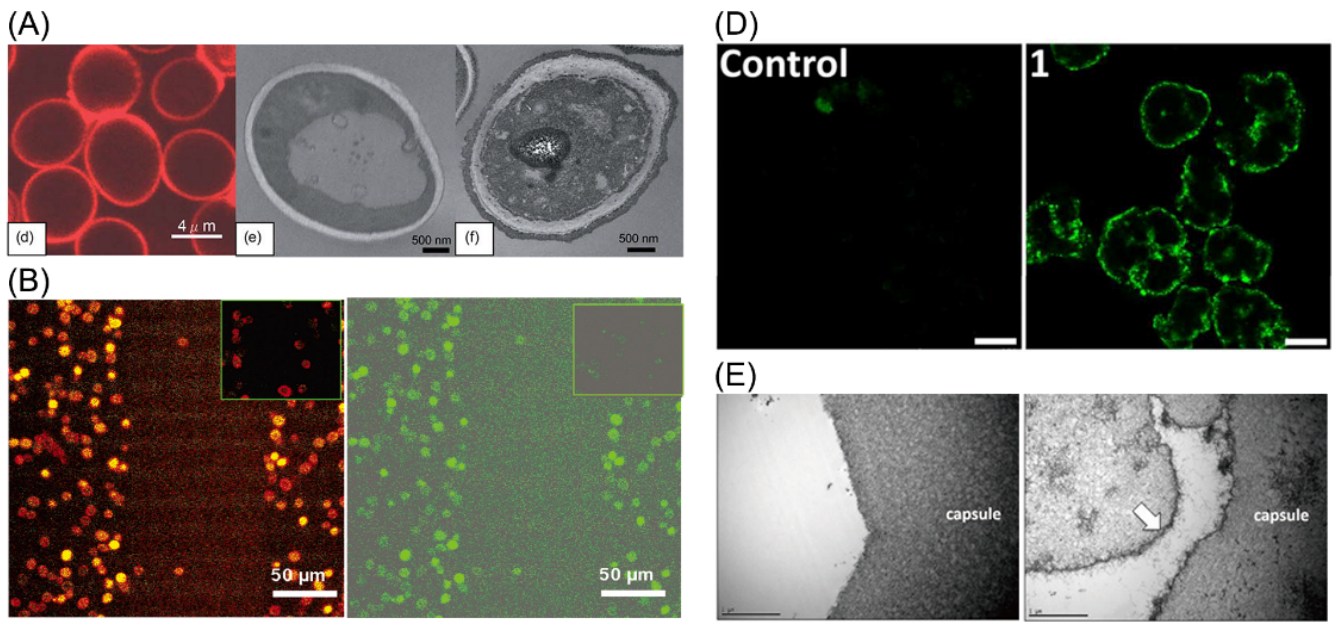

(C)

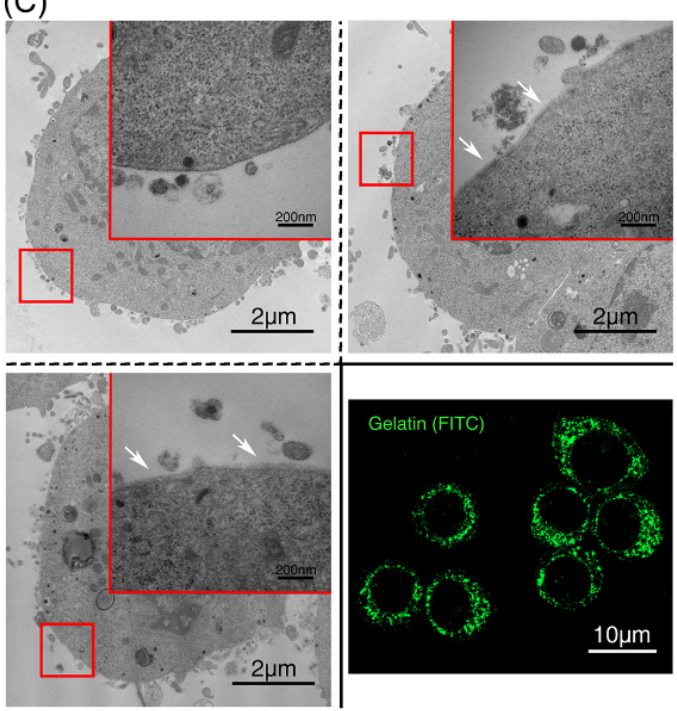

(F)

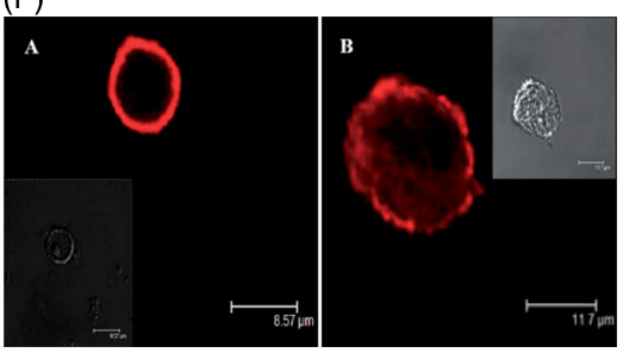

Figure 2. LbL cell encapsulation with polyelectrolytes. (A) Yeast cells encapsulated with PEI, tannic acid and poly(N-vinylpyrrolidone) were verified with fluorescence labeling and TEM. Adapted with permission [38]. Copyright 2011, The Royal Society of Chemistry. (B) Fluorescence imaging of cells encapsulated with PAH and PSS. Adapted with permission [40]. Copyright 2005, American Chemical Society. (C) PC12 cells were encapsulated with gelatin and HA, and underwent TEM and fluorescence imaging. Adapted with permission [48]. Copyright 2018, American Chemical Society. (D) Rat islets were coated with polyamidoamine and alginate. Adapted with permission [63]. Copyright 2013, American Chemical Society. (E) TEM demonstrated the encapsulation by chitosan and alginate. Adapted with permission [76]. Copyright 2021, Korean Endocrine Society. (F) MSCs encapsulated with PLL and HA were investigated with fluorescence and brightfield imaging on different time points. Adapted with permission [87]. Copyright 2007, John Wiley and Sons.

\subsection{Polyanions Utilized for Mammalian Cell Coating}

Generally speaking, both natural and synthetic polyanions are less toxic. Therefore, researchers have a wide selection in performing $\mathrm{LbL}$ technique. 


\subsubsection{Alginate}

Alginate is a natural polyanion from algae. This polysaccharide has a linear structure with variedly arranged residues of $\alpha$-L-guluronic acid and 1, $4^{\prime}$-linked $\beta$-D-mannuronic acid. The constitution of alginate structure depends on the ratio of residues. Guluronic acid is of high affinity to cations, yielding the alginate with a high content of guluronic acid to be solid. Contrarily, alginate becomes soft when there is more mannuronic acid [89]. Owing to this variable feature, alginate receives great attention in material science.

Bivalent ions are sometimes used in crosslinking alginate for encapsulating capsule generating. $\mathrm{Ca}^{2+}$ and $\mathrm{Ba}^{2+}$ are more applied than $\mathrm{Cu}^{2+}$ and $\mathrm{Pb}^{2+}$ which show distinct toxicity. Specifically, with the increase in affinity of ions, rigidity of alginate capsules was tremendously raised [90].

As indicated, pores are easily formed in the alginate capsules, thus still facilitating immune recognition and thereafter reactions [91]. Researchers proved that $\mathrm{Ba}^{2+}$-alginate could only exempt allogeneic grafts from immune attack, instead of the xenogeneic ones [92]. To overcome the obstacle, some researchers applied polycations to bind with alginate, such as PLL and poly-L-ornithine [93,94]. Additionally, PEG, glutaraldehyde and cellulose can also play the similar role [95-97].

Although pores on alginate shell can be covered by LbL coating with polycations, it is important to control the pore size to allow transportation of necessary nutrients and normal functions of surface molecules. Kendall et al. demonstrated that following LbL coating with PLL/poly-L-ornithine and alginate, sensitivity of islets to blood glucose was hindered. The extent of impact was largely dependent on the thickness of the multilayers instead of the islet properties. To be specific, the negative influence of encapsulation could be significantly eliminated when material concentration was less than $0.1 \%$ and coating time within $10 \mathrm{~min}$. Otherwise, the permeability of encapsulation was reduced to give rise to disordered metabolism [98].

Rigid encapsulation with alginate can also be performed via covalent crosslink. Some applied photoactive crosslink for establishing alginate encapsulation, but the process led to obvious toxicity since plenty of redox was generated [99]. Incorporation of hydroxyl and aldehyde groups into alginate is another way to stabilize encapsulation, as well as retain permeability $[100,101]$.

Interestingly, the purity of alginate in encapsulation can also influence the immunoreaction. It is because proteins and endotoxins contained in alginate may induce intensive immune attack when they diffuse [102]. Additionally, it is assumed pathogen-associated molecular pattern molecules with a conserved structure exist in alginate that is impure, activating immune responses and eliciting inflammation [103]. Li and colleagues established encapsulation of NSCs with gelatin and alginate, showing satisfied biocompatibility and neglectable inflammation [22].

\subsubsection{HA}

HA utilized in biomedicine and material science is often obtained from connective tissues. Molecular structure of HA is strictly conserved, consisting of 1,4-b-N-acetyl-Dglucosamine and 1,3-b-D-glucuronic acid. It broadly exists in almost all organism, especially in skin and joint since HA is able to preserve moisture. Meanwhile, the HA which supports ECM plays an important role in the interaction among cells. It also exhibits biodegradability by hepatic cells or hyaluronidase in plasma [104].

An in vivo study showed that HA in blood circulation was immobilized on glycosaminoglycans and membrane receptors via electrostatic interaction. Notably, receptors of HA are not unique and contain several types, such as CD44, intercellular adhesion molecule-1, and hyaluronan mediated motility receptor. Since CD44 is verified to be expressed by tumor cells, HA-CD44 interaction provides a tumor-targeting strategy in design of drug delivery. In short, due to its satisfied features such as bioaffinity, biodegradability and tumor-targeting, HA has been extensively reputed in chemistry, pharmacy, and bioengineering [105]. 
HA can undergo chemical modifications since it has reactive sites, such as N-acetyl, hydroxyl and carboxyl groups. Hydroxyl groups can be simply modified through esterification etherification, or divinyl sulfone coupling. Carboxyl groups modification by amidation or esterification is usually mediated by carbodiimide [106]. Partial and terminal modification generate two common subtypes of HA derivatives [107]. Generally speaking, the partially modified HA is able to be covalently conjugated so that it meets the demands in various applications. At the same time, it should be noted that toxicity, accompanied with the chemical modification, maintains biocompatibility. On the contrary, since terminally modified HA cannot form covalent bonds, its application in bioengineering is limited. Other functional modifications of HA were also reported. For example, the RGD motif was combined with HA to enhance the adhesion [108]. Some even applied methacrylic anhydride to endow HA with photoreactivity [109].

Owing to the natural affinity with ECM, HA attracts great attention in cell engineering, including LbL encapsulation. It has been suggested that MSCs can be encapsulated with HA in chondrogenesis enhancement and supporting matrix fabrication for cartilage regeneration [110]. HA was also utilized in cell encapsulation for nervous system diseases to promote neural repair and glia cell activation [111].

\subsubsection{PSS}

PSS is a synthetic polymer with advantageous hydrophilicity and thermoplasticity. It has already been used to encapsulate red blood cells and islets [112]. However, the weak mechanical rigidity hinders its application, even though PSS and PAH pair prevents immunoreaction when used in LbL encapsulation [113]. Ảkerfeldt et al. demonstrated that encapsulation structure with PAH and PSS was easily destructed by shear force [114]. Even worse, the complement system activation was triggered by PSS, leading to impaired survival of encapsulated mammalian cells [115].

\subsection{Other Materials}

In addition to polyelectrolytes, which are natural or synthetic, nanoparticles can be utilized in single-cell coating. Au and Ag are commonly used particles which were applied to encapsulate fungi. Surprisingly, the coated fungi exhibited contrary phenomena in biological processes and morphologic features (Figure 3A) [116]. To improve the electrochemical features, such as conductivity, carbon nanotubes were used to encapsulate S. cerevisiae [117]. Graphite oxide also presented increased conductivity and antibacterial activity with biological compatibility [118].

Meanwhile, magnetic nanoparticles have drawn attention in fabrication of bioreactors, biosensors, and single-cell encapsulation since they provide the encapsulation system manipulability through magnetic field (Figure 3B) [119]. In a study, encapsulation of yeast cells with magnetic nanoparticles still maintained the enzymatic activities, so that a manipulable biocatalyst was produced [120]. Since the nanoparticles directly contact cells, they influenced the cell survival unavoidably. To deal with the problem, PAH was linked to magnetic nanoparticles and improved viability was achieved owing to the prevention of particles from entering cells [121]. This modified nanoparticle was further applied in multitypes of mammalian cells to explore the cellular functions since the viability of mammalian cells could be preserved [122]. It should be noted that most nanoparticles would be internalized into cells as time passed, and the extent was related to the properties of cell membrane which affected interactions. Cells in rapid proliferation tended to internalize nanoparticles faster [123].

Biology-inspired materials are also attractive due to their bioaffinity. Mussel-inspired LbL coating takes advantage of well-defined adhesiveness of mussel which is attributed to polydopamine. Yang et al. coated polydopamine on yeast cells individually and found that cell survival could be preserved and proliferation manipulated (Figure 3C) [124]. Another study applied dopamine and HA to construct LbL films. This scaffold was shown to be effective in eliminate reactive oxygen species (ROS) and promote osteogenesis, and thus 
demonstrated great promises in cell therapy [125]. Deoxyribonucleic acid (DNA) is another bio-derived polymer in LbL coating. It was used in encapsulation of multiple cell types and provided a precisely programmed encapsulation pattern (Figure 3D) [126].

(A)

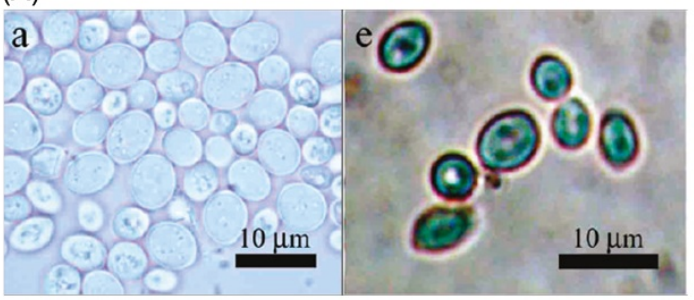

(B)
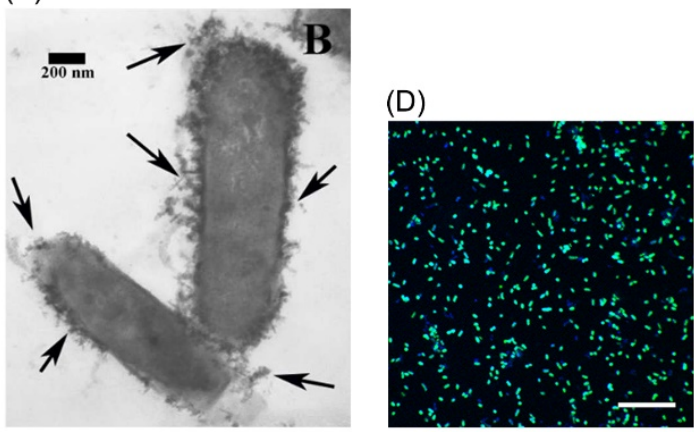

(C)
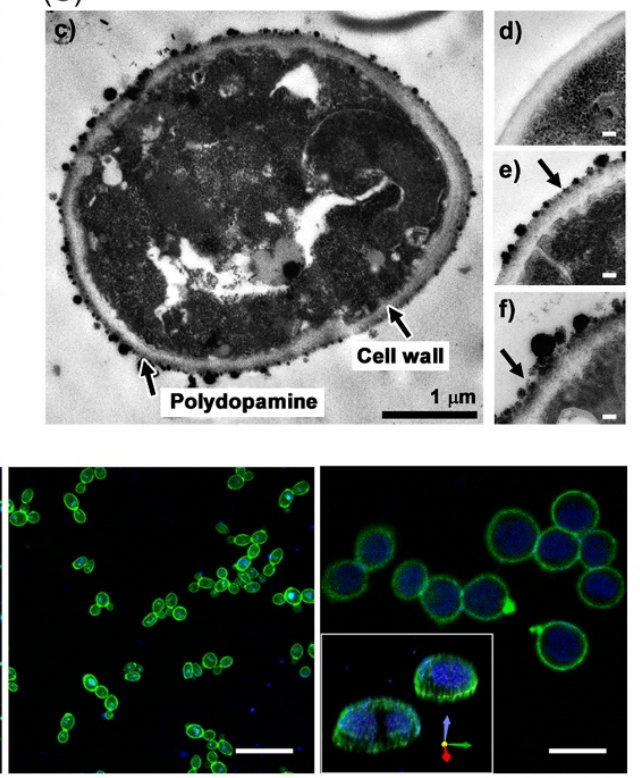

Figure 3. LbL cell encapsulation with atypical methodologies. (A) Optical imaging of uncoated yeasts and yeasts coated with Ag nanoparticles. Adapted with permission [116]. Copyright 2009, American Chemical Society. (B) Borkumensis was encapsulated with magnetic nanoparticles as exhibited under TEM. Adapted with permission [119]. Copyright 2016, American Chemical Society. (C) TEM showed mussel-inspired encapsulation of yeast cells. Adapted with permission [124]. Copyright 2011, American Chemical Society. (D) Bacteria, eukaryotic cells and mammalian cells were proved to be encapsulated with fluorescence-labeled DNA polymers. Adapted with permission [126]. Copyright 2019, The Authors.

Table 1. Representative examples of materials applied in LbL cell encapsulation.

\begin{tabular}{|c|c|c|c|c|}
\hline \multicolumn{2}{|c|}{ Materials } & Cell Types & Applications & Reference \\
\hline \multirow{3}{*}{$\begin{array}{c}\text { Polycations } \\
\text { (for non-mammalian cells) }\end{array}$} & PEI & Yeast cells & Function maintenance & [38] \\
\hline & PAH & Yeast cells & Cell immobilization & [40] \\
\hline & PDDA & Allochromatium vinosum & Physical protection & [43] \\
\hline \multirow{5}{*}{$\begin{array}{c}\text { Polycations } \\
\text { (for mammalian cells) }\end{array}$} & Gelatin & PC12 cells; NSCs & Protection and payload delivery & {$[48,49]$} \\
\hline & Cationic cellulose & Islet cells & Function maintenance & [57] \\
\hline & Polyamidoamine & Islet cells & Immunocamouflage & [63] \\
\hline & Chitosan & MSCs; Islet cells & Directed differentiation; & {$[75,76]$} \\
\hline & PLL & MSCs & Function maintenance & [87] \\
\hline \multirow{3}{*}{ Polyanions } & Alginate & Fibroblasts, endothelial cells & Oxidative stress reaction control & [101] \\
\hline & HA & MSCs; NSCs & Directed differentiation & {$[110,111]$} \\
\hline & PSS & Islet cells & Immunocamouflage & [115] \\
\hline \multirow{6}{*}{ Others } & Metallic nanoparticles & S. cerevisiae & Function maintenance & [116] \\
\hline & Carbon nanotubes & S. cerevisiae & Toxicity evaluation & [117] \\
\hline & Graphite oxide & S. cerevisiae & Antimicrobial & [118] \\
\hline & Magnetic nanoparticles & $\begin{array}{l}\text { Alcanivorax borkumensis; } \\
\text { Yeast cells; HeLa cells }\end{array}$ & $\begin{array}{l}\text { Cell functionalization; } \\
\text { Spatial locomotion }\end{array}$ & {$[119,120,122]$} \\
\hline & $\begin{array}{l}\text { Mussel-inspired } \\
\text { polydopamine }\end{array}$ & Yeast cells & Cell protection & [124] \\
\hline & DNA molecules & $\begin{array}{l}\text { Escherichia coli, Yeast cells, } \\
\text { MCF-7 cells }\end{array}$ & Function maintenance & [126] \\
\hline
\end{tabular}




\section{Interactions of LbL Multilayers with Interfaces}

LbL self-assembly is based on electrical adsorption which will change the properties of attached substances. Again, the interaction itself also affects the multilayers features. In this context, a comprehensive understanding of principles of LbL multilayers is important for further applications.

Till now, people have obtained detailed understanding of the characteristics of interfaces. To be specific, the interacting interfaces can be classified into planar surface and colloidal particle. Techniques, such as surface forces apparatus, atomic force microscope, and total internal reflection fluorescence, have come into use for investigation of interacting forces with the planar surface [127-129]. On the other hand, colloidal particles are studied via rheological measurement, time-resolved light scattering, and turbidity measurement [130-132]. Strong polyelectrolytes can always have stable charges, such as branched PEI and PSS. Conversely, the electrical property of weak polyelectrolytes is greatly influenced by environmental $\mathrm{pH}$ and ions, such as type A gelatin, linear PEI, and PLL. By titration and electronic field measurement, extent of ionization was evaluated [133].

\subsection{Properties of Materials Adsorption}

The interaction of polymers with the attached substances is based on the electrostatic force. Due to the fact that most polyelectrolytes are hydrophobic, interactions are largely dependent on force of van der Waals and hydration [134].

\subsubsection{Interactions on Planar Interfaces}

Observation of materials stacking was conducted by Kargl et al. [135]. It was found at the beginning, the thickness of multilayers increased, indicating that polyelectrolytes binding was in progress. With time going on, encapsulation thickness did not increase due to the saturation of surface materials [136]. When the surface was rinsed, LbL multilayers were still maintained, indicating that the interaction within LbL self-assembly was firm [135]. However, detachment might happen to small-molecule polymers and it was particularly obvious when solution ingredients varied [137].

As suggested, the degree of material attaching is proportional to concentration, which was even verified in a math model [127]. This effect is common in most cases, although hydrodynamics affects it sometimes [138]. As concentration of polyelectrolytes increased, the adsorption speed increased accordingly. They explained it with limited relaxation of the multilayers since the lateral relaxation of encapsulating polymers would be hindered by fast attachment of the surrounding materials when concentration increased. This mechanism generally existed in studies of protein interaction [139].

\subsubsection{Interactions on Colloidal Particles}

Polyelectrolytes are able to be absorbed on colloidal surfaces once LbL self-assembly is performed. Similar to situations for planar surface, materials can attach to particles to reach saturation when excessive materials exist. Therefore, polyelectrolytes should be more widespread for a homogenous distribution on particles, otherwise there would be discrepancy in degree of encapsulation on the surface [140]. The formed multilayers were proved to be irreversible [141]. Additionally, through electrophoresis, the amount of materials on surface of particle can be precisely obtained. Nonetheless, the dynamic kinetics in the encapsulation process could still influence the results more or less [142].

\subsection{Properties of Polyelectrolyte Multilayers}

\subsubsection{Amount of Adsorbed Materials}

In encapsulation with $\mathrm{PDDA}$ and $\mathrm{SiO}_{2}$ in aqueous solution of $50 \mathrm{mM}$ salt, the saturated mass of PDDA was approximately $0.3 \mu \mathrm{g} / \mathrm{mm}^{2}$ since one layer of adsorbed atom was 1.0 to $2.0 \mu \mathrm{g} / \mathrm{mm}^{2}$. Further, when polyelectrolytes interaction reached saturation, the adsorption became 0.01 to $1.0 \mu \mathrm{g} / \mathrm{mm}^{2}$ [143]. 
The adsorbed mass of materials is closely related to materials' innate characteristics and solution ingredients. Molecular weight of polyelectrolytes, concentration of ions and electrical charge density are key factors. To be specific, the amount of branched polyelectrolytes in LbL adsorption is proportional to the molecular mass [144]. Meanwhile, the importance of polymer concentration was suggested by Godman et al. They found that interaction of polyelectrolytes could be reversed under the circumstances of weakly charged polyelectrolytes or high-concentration solutions [145].

There is great variation in polyelectrolytes' charge density which influences hydrophility accordingly. By means of adding weak ions or tuning environmental $\mathrm{pH}$, polymers' charge density may be significantly affected. It should also be noticed that the influence is different between bound and unbound $\mathrm{LbL}$ multilayers, since ionization may be in progress with LbL assembling. In particular, the adsorbed materials increased with high charges of substrates and low charges of materials, and absorption reaches to maximum with the polymer charge at a low level [146].

\subsubsection{Morphology of Polyelectrolyte Multilayers}

In LbL self-assembly, polymers attach to each other by electrostatic adsorption. The chains generate repelling force at the same time and thus lead to the formation of potential space within multilayers. Meanwhile, the electrostatic force which is attractive within multilayers flattens chains of polyelectrolytes, leading to heterogeneously arranged thin films. On the contrary, the polymer films are homogeneous when weak polyelectrolytes and solution of strong ions are applied [133].

Moreover, $\mathrm{Xu}$ and colleagues applied techniques, such as dynamic light scattering and quartz crystal microbalance in measuring thickness of the multilayers, which was suggested to be at nanometer-scale [147]. Based on the fact that polymer chains diameter was from 20 to $100 \mathrm{~nm}$, it indicated that these chains were significantly compressed during the LbL self-assembly procedure. Implied from the layer thickness, water accounted for around $20-60 \%$ in the pressed materials. Yet, in solutions of high-concentration salt, multilayers tended to swell and form pores. Selin et al. proved that LbL films were thickened when salt concentration and molecular weight of materials were elevated, as well as the charge was reduced [148].

Although a similar conclusion can be drawn via dynamic light scattering, the result obtained from surface techniques is larger and indicates the swollen material films. Although the difference may be determined by different substrates, it is also explained by sub-layers existing in a single film. The thickness of the sub-layer is greatly dependent on the solution concentration, giving rise to the observed differences by the two methodologies. It is noteworthy that systematic errors in these techniques cannot be fully avoided since the LbL layers are ultra-thin and easily influenced by environment [149].

Lateral heterogeneity of attached materials has been verified by atomic force microscopy. It is extremely significant when there are potent polyelectrolytes and a low salt solution. With the LbL self-assembly using branched PAA, researchers verified that even if multilayers interaction reaches saturation, potential space is still within the films because the branched materials possess repulsive force [150]. The extent of lateral heterogeneity of branched PAMAM films was also quantified with atomic force microscopy at molecule-scale [151]. For films of linear materials, although their statistical features can be obtained via atomic force microscopy, detailed delineation of saturated multilayers of attached linear materials is still lacking [152]. In the meantime, it was acknowledged that PAMAM-PSS films were heterogeneous, examined by direct force measurement [153]. Therefore, the above studies suggested that linear polyelectrolytes are inclined to form LbL multilayers with homogeneity. In addition, similar to the disturbed lamellar phase, homogeneous multilayers are usually formed by hydrophobic polyelectrolytes which are weakly charged [154]. 


\subsection{Charge Balance of LbL Multilayers}

\subsubsection{Charge Reversal}

Charge reversal is a pivotal characteristic of LbL adsorption, resulting from overcharging. It is well known that polyelectrolytes and substrates bind because of electrostatic force. Therefore, coating materials may fall from the substrates if they possess the same charges. Nonetheless, since adsorbed polyelectrolytes in LbL self-assembly are heterogeneous, only the features of substance in assembly are crucial. In this context, once there is one empty binding site, a molecule of polyelectrolyte can attach [155]. In addition, there are also interacting forces within the LbL formation, such as van der Waals and hydrophobic forces, which are unaffected by interface charges [156,157].

Detection of polymer charges can be performed with electrokinetic techniques which involve electrophoresis and surface potential monitoring. The former method is for measuring electrophoretic kinetics of particles via mathematic models. The latter one can be used for detection of planar substrates by relative values obtained through direct force measurement [158]. Specifically, amidine particles were applied to exhibit the charge reversal for particles [159]. As it was proved, charges of non-coated particle are reversed by adsorbed polymers to show opposite charges. During the LbL self-assembly, when polyelectrolyte is added to reach the threshold, surface charge of particles becomes neutralized. With the continuous addition of polyelectrolyte to be excessive, charges on particles accumulate until saturation [140]. Measurement of charge reversal on planar substrates was conducted via streaming potential detection on poly (allyl amine)-mica interaction [160]. With the increased amount of polyelectrolyte, saturation was gradually reached and the charges of surface were reversed. They suggested an incubation time of $20 \mathrm{~min}$ and application of low-concentration materials to attenuate the reaching of plateau.

\subsubsection{Charges Distribution in the Multilayer Structure}

Patterns of charge density and surface potential have already been described. For example, when the surface is positively charged, these local charge groups are compensated by the reduction in positive charges and accumulation of negative charges. The cationic charges of saturated polyanion are overcompensated to give rise to anionic surface [161]. The slow progress of the compensation implied the decreased net charges on the substrate.

The details of variation in charge distribution within LbL structure can be examined. The mechanism is based on the threshold value of charge reversal, since chemical titration is used to inspect the charges when the interface charge becomes neutral on this threshold. Additionally, counterions play an important role in charge balance, especially for dendritic materials and low-charge substrates. For instance, counterions are responsible for the compensation of $90 \%$ of charges generated in LbL films by PEI and PAA. Even for saturated films, only a very little part of the charges is compensated by free polyelectrolytes. The lateral deviation led by heterogeneous polyelectrolytes can likely explain the differences residing in adsorbed materials and exhibited charges [162].

The charge reversal point shift can be interpreted with the solid stoichiometry which demonstrates the necessary demand for weakly charged polymers in the charge compensation [163]. Similar to this tendency, a small amount of polyelectrolytes is required for compensating the low charges on substrates. Simultaneously, the requirement for $\mathrm{pH}$ of solutions which involve weakly charged polymers can be naturally acknowledged [164]. The reduction in $\mathrm{pH}$ may lead to an increase in the charge of weak polycations, therefore the reversal threshold inclines to shift to higher $\mathrm{pH}$ with strengthened polyelectrolyte interaction on surface with solid charge distribution [165]. This same situation happens in the combination of weak-acid or amphiprotic substrates with strongly-charged cationic materials. Under the contrary conditions that feeble polyanions adsorb to cationic substrate or potent polyanion attaches to feeble alkaline or amphiprotic surfaces [166]. However, the findings could not be applied to $\mathrm{pH}$-sensitive materials and surfaces.

As verified, the shift of reversal point is also related to changes of molecular weight. For instance, when molecular weight of materials increases, the charges are greatly compen- 
sated in a PAA adsorption study. Therefore, the net charge increase lags behind molecular weight increase, and, thus, the reversal point deviates to high material doses. However, it is not applicable for linear polymers because they often interact to form a more flattened pattern, and the variations in stoichiometry are not proportional to molecular mass changes [167].

\section{Functional Regulation of Cells by LbL Encapsulation}

In recent years, regulation of cell functions, such as viability, proliferation, differentiation, migration, and immune disguise, has attracted significant attention. Yang and Wang have illustrated that the encapsulation shell prevented cells from biological, chemical, and physical damages $[168,169]$. In addition to protection, functional regulation can be realized by modification of materials. It is certain that an appropriate duration of encapsulation polymers is required for regulating cellular functions.

Biological hazards can be protected from functioning. Nguyen et al. encapsulated yeasts with a PAH and PSS pairing, and found that the cells were protected from enzymatic activity of lysosomes [170]. Moreover, mammalian HeLa cells which were encapsulated with gelatin and PEG could be greatly protected from the lytic enzymes, such as trypsin. In the latter case, more than $50 \%$ of coated cells stayed alive, and there were only $27 \%$ of untreated cells surviving [171] (Figure 4A). The mechanism was regarded as the reduced permeability of the adverse factors by encapsulation.

Protection of encapsulation against high temperature has also been verified. GonzálezFerrero et al. kept encapsulated Lactobacillus cells under heat stress and their survival could still be retained [172]. The heat-resistance effect was also investigated in encapsulation of yeasts with $\mathrm{SiO}_{2}$ and it could be interpreted by its effect on water retention via the silica layers [173] (Figure 4B).

Studies have demonstrated the protective effects of encapsulation against physical factors, such as centrifuge and osmotic pressure. S. cerevisiae was encapsulated with silica-based multilayers and exhibited satisfied viability in water for a long period [174] (Figure 4C). Maheshwari et al. even applied nanoparticle-modified graphene in S. cerevisiae encapsulation to preserve them in water for one week [175]. For mammalian cells, a gelatinfibronectin pair was used in single-cell encapsulation of HepG2. Following centrifuge with ultra-high speed, uncoated cells exhibited a survival rate of $10 \%$ while the encapsulated cells show the rate of over $80 \%$ [176].

Sometimes encapsulation may negatively influence the cellular functions. Yeast proliferation was shown to be interfered following encapsulation with $\mathrm{SiO}_{2}$ multilayers and the effect could be reversed when thinner $\mathrm{SiO}_{2}$ layers were formed [41] (Figure 4D). The reason may be underlay by the obstruction of nutrients and wastes. Further, mechanical properties of the encapsulation multilayers, for example rigidity, were suggested to pose a great impact on the proliferation of coated cells. Ishihara and colleagues performed encapsulation on HeLa cells, demonstrating that the increased rigidity of encapsulation structure could obviously inhibit the proliferation; and the proliferation rate could be recovered when coating layers were disrupted [177]. 
(A)
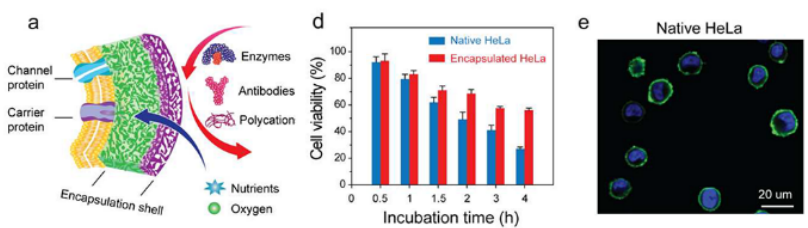

(C)

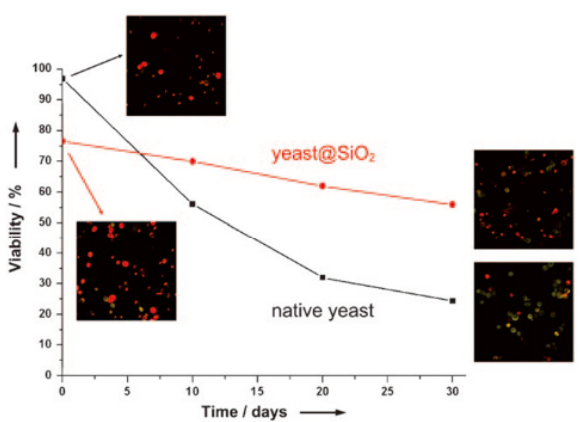

(D)

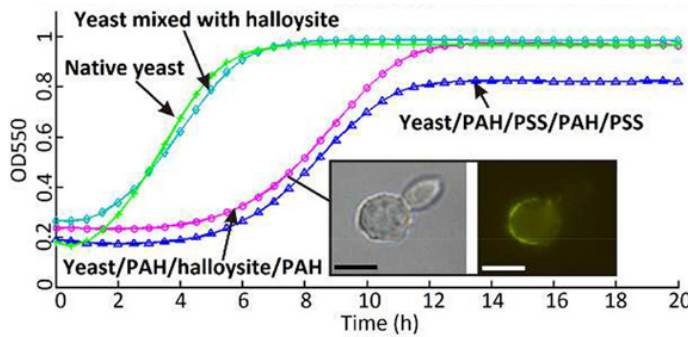

(B)
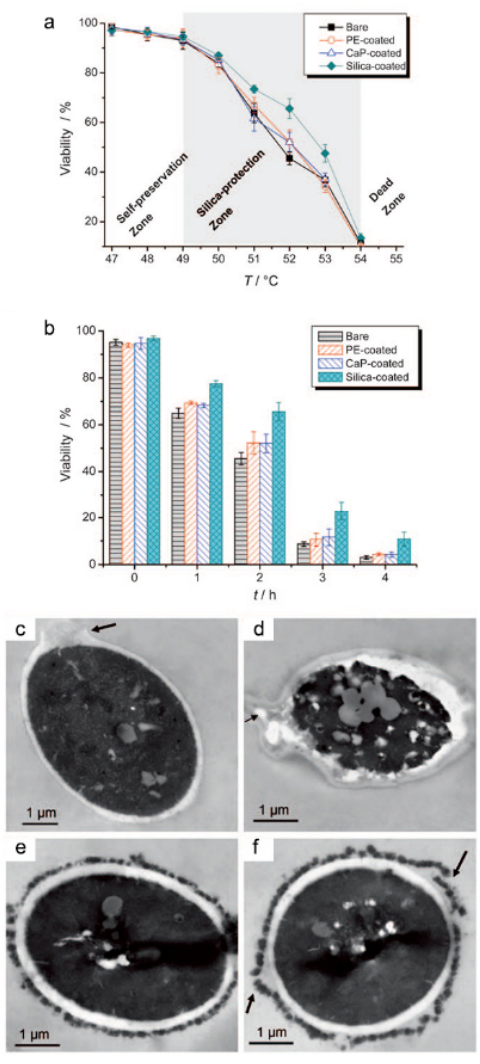

Figure 4. Functional regulation by cell encapsulation. (A) Yeasts can be protected from enzymes by encapsulation with gelatin and PEG. Adapted with permission [171]. Copyright 2017, Elsevier. (B) Thermo-resistance imposed by cell encapsulation. Adapted with permission [173]. Copyright 2010, John Wiley and Sons. (C) Encapsulated cells exhibited higher viability in water for a long term. Adapted with permission [174]. Copyright 2009, John Wiley and Sons. (D) Proliferation of yeast cells can be tuned by encapsulation. Adapted with permission [41]. Copyright 2013, Royal Society of Chemistry.

\section{Applications of Drug Delivery via LbL Cell Encapsulation}

The controllable drug delivery has great potential in many diseases with a deteriorative progression. These diseases usually require sustained effects which can hardly be obtained from traditional therapies. Nanoparticles, such as lipid-based carriers, were usually applied in drug delivery for these diseases, since they exhibited a large surface area for drug loading and different binding sites for hydrophilic/hydrophobic/amphiphilic molecules [178]. However, the cytotoxicity, tissue irritation, and uncontrolled diffusion were supposed to be the drawbacks $[179,180]$. In comparison, LbL cell encapsulation often applied natural polymers which avoided cell or tissue damage after transplantation, and was able to protect encapsulated cells from damaging factors via molecule isolation and permit diffusion of nutrients for metabolism [181]. Additionally, the incorporation of payloads on encapsulation structures helped the controlled release of drugs. Therefore, the "cell encapsulation + payloads" complex was expected to facilitate the simultaneous transplantation of cells and bioactive agents, showing great potentials in transplantation therapy.

Payload diffusing from the LbL multilayers and the degradation of LbL materials largely determine the speed and degree of drug release from the LbL structure [182]. The multilayers degradation was verified to be resulted from material degradation and interaction of ions with counterions and film swollen [183,184]. Controlled drug delivery via LbL benefited due to reduced cytotoxicity, lowered drug dose and enhanced therapeutic effects (Figure 5). 


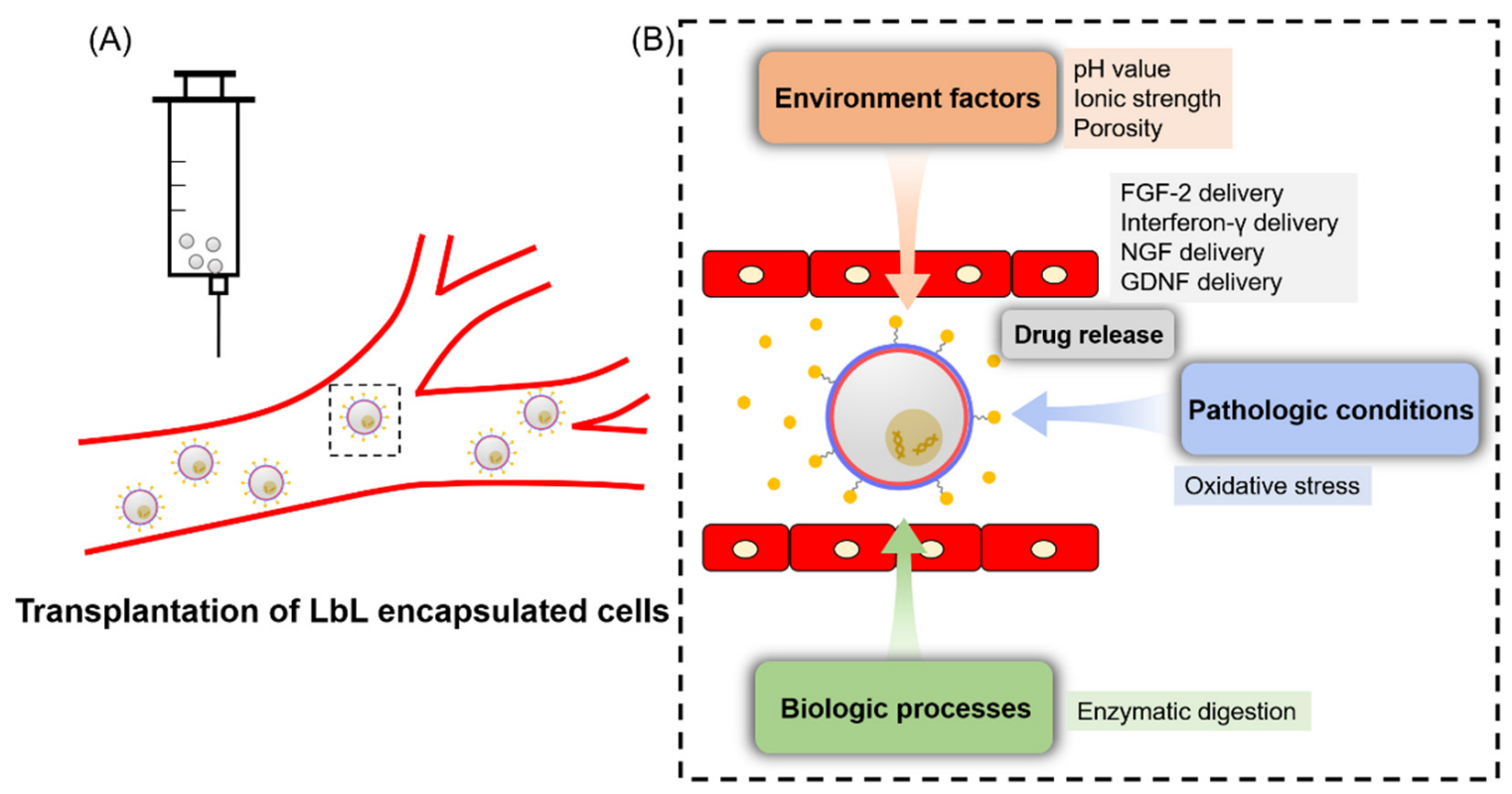

Figure 5. LbL cell encapsulation for drug delivery can be tuned by multiple factors. (A) This technique can be applied in cell transplantation therapy for various diseases. (B) Drug delivery is able to be manipulated by different factors and representative works are listed.

To achieve a sustained drug release from LbL cell encapsulation, material layers can be thickened and covalent conjugation of drugs can be applied [185,186]. On one hand, due to the multilayers structure, staged drug releasing of multiple regulators can be realized in previous studies $[187,188]$. On the other hand, a triggered release is required under some circumstances. Therefore, responsive materials are employed in the formation of LbL encapsulation [189]. The triggerable feature can be the innate property of coating materials, such as the $\mathrm{pH}$-sensitivity in weakly charged polymers, or crosslinking of responsive groups on materials $[190,191]$. There are also strategies of LbL encapsulation in cell targeting by materials' nature or functional modification. For example, CD44 which is predominant on tumor cells can be specifically recognized by HA [192]; conjugation of antibodies on polyelectrolytes facilitates the targeting of LbL structure to the ligands of interest [193]. As such, desired materials on demand are able to be constructed for aiming at specialized therapeutic outcomes by LbL cell encapsulation.

\subsection{Environment-Adjustable Release}

By utilization of polyelectrolytes in LbL encapsulation, especially the weak ones, the electrostatic interaction can be conveniently adjusted by different stimuli [154]. Yuan and co-workers synthesized porous materials for LbL drug delivery, and the process can be tuned by $\mathrm{pH}$. To be specific, when $\mathrm{pH}$ value was higher than 9.6, a sustained release over 16 days was achieved; when lower than 3.2, a large number of residual drugs were kept in materials for at least 3 months [194]. The feature is attractive in anti-cancer research since the $\mathrm{pH}$ in the tumor microenvironment is acidic. For example, Zhao and colleagues developed a doxorubicin delivery system via encapsulation with chitosan and HA, showing a faster releasing rate in carcinogenic sites than in others [195]. Additionally, co-delivery of drugs via LbL in a pH-triggered manner has been extensively applied by Li's group these years, and it brought the on-demand delivery and sustained release of multiple drug types [196-198].

Some people adjusted ionic strength to control the LbL architecture and, thus, the loaded compounds. For LbL multilayers with PDADMAC and PAA, when the ionic strength was elevated to $0.6 \mathrm{M}$, disassembly of LbL films took place [199]. Similarly, hydrogen bond-based encapsulation could also be tuned by the addition of salt solutions [200]. 
Porosity of LbL encapsulation can become another factor. In a study applying PAH and PSS as the encapsulation polyelectrolytes, an increase in ethanol proportion in the medium greatly affected the porosity of multiplayers and then facilitated the payload release [201]. The controlled delivery of urease was realized by Lvov et al. by taking advantage of this feature [202]. Although this is effective in modifying drug delivery, the addition of ethanol can inhibit the bioactivity of the carried compounds to some extent.

\subsection{ROS-Controlled Release}

Due to the fact that peroxidative conditions exist in many different diseases, ROSresponsive materials have received great chances for inducing controlled payload release following transplantation [203]. Presumably, the ROS-responsive encapsulation structure keeps relatively stable in circulation, and it is disrupted to release drugs after getting into the pathologic sites which present the condition of abundant ROS. Yan and co-workers fabricated the ROS-responsive encapsulation system in poly(vinylpyrrolidone) and poly(methacrylic acid) multilayers which were coupled with bisazide as the triggering linker for conveying DOX [204]. This controlled delivery system exhibited higher efficiency in cancer cell elimination. In another case, researchers applied folic acid as the ROS-sensitive linker in the encapsulation architecture to deliver Luteolin, demonstrating ROS-triggered delivery and anti-tumor effects [205].

\subsection{Biology Induced Release}

A remarkable feature of this strategy is the independence on external inducers. Physiological factors and enzymes can be two major types in the biology-controlled drug delivery. The former factors involve $\mathrm{pH}$ value and salt components, which can probably influence the cargo release from LbL multilayers without external stimuli [206]. Under the physiological conditions, compounds release is a passive process after the multilayers gradually disassemble or results from the interruption of chemical bonds between compounds and the polyelectrolytes $[207,208]$. The latter methodology utilizing enzymatic activity is based on materials which are also the substrates of enzymes. This has been proven in LbL encapsulation with polysaccharides and peptides. For example, LbL multilayers formed by poly(lactic acid) were degraded via the effect of $\alpha$-chymotrypsin [209]. In animal studies, proteases were demonstrated to digest LbL films constructed with dextran and poly(Larginine). Another study took advantage of an enzyme which was put inside LbL films with poly(L-lactide) and poly(D-lactide) to adjust their degradation time [210].

\subsection{Drug Delivery via Cell Encapsulation}

In many diseases, cell transplantation presents great potential for providing cell supplementation and nutrient secretion. As previously mentioned, LbL encapsulation protects grafted cells and those diverse strategies of drug delivery via LbL self-assembly further aid the effect of cell therapies.

Fibroblast growth factor-2 (FGF-2) was incorporated on gelatin and modified gelatin, and could form an LbL structure with alginate on dermal papilla cells, which are stem cells residing in hair follicles. The growth factor was suggested to be conveyed to aid hair cell survival and proliferation. The strategy was also verified to be effective in subcutaneous transplantation [23]. Ham and colleagues crosslinked interferon- $\gamma$ on coating materials and then performed LbL encapsulation on neural stem cells. The crosslinked compound successfully promoted the neuronal differentiation of stem cells. Furthermore, in vivo experiments proved the improvement in development of neural tube by the interferon- $\gamma-$ modified encapsulation of neural stem cells [211].

In cell therapy for nervous system diseases, the blood-brain barrier is always an obstacle for delivering therapeutic compounds into brain tissue. The drugs should also maintain a certain quantity and quality to generate effects. LbL cell encapsulation as a carrier is bringing increasing prospects in treating central nervous system disorders such as Huntington's Disease $[212,213]$. Nerve growth factor (NGF) was tethered with polyethersulfone 
in the fibroblast encapsulation for treating neurodegenerative diseases [214]. Researchers took advantage of human retinal epithelial cells, which are known as ARPE-19 in the cell encapsulation. Astonishingly, these coated cells retained their viability in the brain and eye for years, since the well-defined coating films protected cells from the inflammatory factors and the grow factor effects simultaneously [215,216]. The reinforced glial cell-derived neurotrophic factor that was released from C2C12 myoblasts was designed by Perez-Bouza et al. and the transplantation of which provided a sufficient source of the neurotrophin for Parkinson's Disease patients [217].

\section{Conclusions}

This review summarized the basics and applications of LbL encapsulation. Different types of materials, both natural and synthetic, can be utilized in the formation of multilayers. This technique views cells not just as the physically encapsulated cores, but as functionally modified organisms. The details of interaction within LbL films were also sophisticatedly depicted. Since LbL encapsulation works as a capsule on cells, it certainly affects the cellular functions. Even more, the coating materials can be modified to gain the required functions in drug delivery under certain conditions, for example, targeting delivery, sustained delivery, multi-load delivery, and responsive delivery. These features largely extended the applications of LbL cell encapsulation in either basic or clinical researches.

It is a certainty that LbL cell encapsulation is still in its infant stage. There are challenges involving design of responsive materials and delicate regulation of cellular function under specific disease environment. The shortage of clinical trials is another concern to further apply this engineering strategy. Nonetheless, in the future, LbL cell encapsulation will contribute to the development of diverse fields in creative ways.

Author Contributions: W.L.: draft of manuscript; X.L.: literature collection and drafting; H.F.: manuscript revision; B.L.: manuscript revision; J.K.: manuscript revision; M.X.: project design. All authors approve the submitted version. All authors have read and agreed to the published version of the manuscript.

Funding: This research was funded by National Natural Science Foundation Youth Project (No. 81901213) and Youth Project of Military Medical Science (No. 21QNPY013).

Institutional Review Board Statement: Not applicable.

Informed Consent Statement: Not applicable.

Conflicts of Interest: The authors declare no conflict of interest.

\section{References}

1. Guerzoni, L.P.B.; Tsukamoto, Y.; Gehlen, D.B.; Rommel, D.; Haraszti, T.; Akashi, M.; De Laporte, L. A Layer-by-Layer Single-Cell Coating Technique To Produce Injectable Beating Mini Heart Tissues via Microfluidics. Biomacromolecules 2019, 20, $3746-3754$. [CrossRef] [PubMed]

2. Zhang, Y.; Zhang, Z.; Wang, Z.; Pan, H.; Lin, Y.; Chang, D. Sensitive detection of prostate-specific antigen based on dual signal amplification of Fc@MgAl-LDH and NH(2)-MIL-101(Fe). Biosens. Bioelectron. 2021, 190, 113437. [CrossRef] [PubMed]

3. Bocanegra-Rodríguez, S.; Molins-Legua, C.; Campíns-Falcó, P.; Giroud, F.; Gross, A.J.; Cosnier, S. Monofunctional pyrenes at carbon nanotube electrodes for direct electron transfer $\mathrm{H}(2) \mathrm{O}(2)$ reduction with HRP and HRP-bacterial nanocellulose. Biosens. Bioelectron. 2021, 187, 113304. [CrossRef] [PubMed]

4. Oliveira, M.B.; Hatami, J.; Mano, J.F. Coating Strategies Using Layer-by-layer Deposition for Cell Encapsulation. Chem. Asian J. 2016, 11, 1753-1764. [CrossRef] [PubMed]

5. Liu, T.; Wang, Y.; Zhong, W.; Li, B.; Mequanint, K.; Luo, G.; Xing, M. Biomedical Applications of Layer-by-Layer Self-Assembly for Cell Encapsulation: Current Status and Future Perspectives. Adv. Healthc. Mater. 2019, 8, e1800939. [CrossRef] [PubMed]

6. Richardson, J.J.; Björnmalm, M.; Caruso, F. Multilayer assembly. Technology-driven layer-by-layer assembly of nanofilms. Science 2015, 348, aaa2491. [CrossRef]

7. Zhao, S.; Caruso, F.; Dähne, L.; Decher, G.; De Geest, B.G.; Fan, J.; Feliu, N.; Gogotsi, Y.; Hammond, P.T.; Hersam, M.C.; et al. The Future of Layer-by-Layer Assembly: A Tribute to ACS Nano Associate Editor Helmuth Möhwald. ACS Nano 2019, 13, 6151-6169. [CrossRef]

8. Decher, G.; Hong, J.; Schmitt, J. Buildup of ultrathin multilayer films by a self-assembly process: III. Consecutively alternating adsorption of anionic and cationic polyelectrolytes on charged surfaces. Thin Solid Films 1992, 210, 831-835. [CrossRef] 
9. Hou, S.; Li, W.; Watzele, S.; Kluge, R.M.; Xue, S.; Yin, S.; Jiang, X.; Döblinger, M.; Welle, A.; Garlyyev, B.; et al. Metamorphosis of Heterostructured Surface-Mounted Metal-Organic Frameworks Yielding Record Oxygen Evolution Mass Activities. Adv. Mater. 2021, 33, e2103218. [CrossRef]

10. Zhang, S.; Yang, Y.; Tong, Z.; Gao, B.; Gao, N.; Shen, T.; Wan, Y.; Yu, Z.; Liu, L.; Ma, X.; et al. Self-Assembly of Hydrophobic and Self-Healing Bionanocomposite-Coated Controlled-Release Fertilizers. ACS Appl. Mater. Interfaces 2020, 12, $27598-27606$. [CrossRef]

11. Barberio, A.E.; Smith, S.G.; Correa, S.; Nguyen, C.; Nhan, B.; Melo, M.; Tokatlian, T.; Suh, H.; Irvine, D.J.; Hammond, P.T. Cancer Cell Coating Nanoparticles for Optimal Tumor-Specific Cytokine Delivery. ACS Nano 2020, 14, 11238-11253. [CrossRef] [PubMed]

12. Leporatti, S.; Voigt, A.; Mitlöhner, R.; Sukhorukov, G.; Donath, E.; Möhwald, H. Scanning force microscopy investigation of polyelectrolyte nano-and microcapsule wall texture. Langmuir 2000, 16, 4059-4063. [CrossRef]

13. Neu, B.; Voigt, A.; Mitlohner, R.; Leporatti, S.; Gao, C.Y.; Donath, E.; Kiesewetter, H.; Mohwald, H.; Meiselman, H.J.; Baumler, H Biological cells as templates for hollow microcapsules. J. Microencapsul. 2001, 18, 385-395. [CrossRef] [PubMed]

14. Sugunan, A.; Melin, P.; Schnürer, J.; Hilborn, J.G.; Dutta, J. Nutrition-Driven Assembly of Colloidal Nanoparticles: Growing Fungi Assemble Gold Nanoparticles as Microwires. Adv. Mater. 2007, 19, 77-81. [CrossRef]

15. Zhang, B.; Yang, S.; Zhang, Y.; Wang, Q.; Ren, T. Biotemplate-directed fabrication of size-controlled monodisperse magnetic silica microspheres. Colloids Surf. B 2015, 131, 129-135. [CrossRef] [PubMed]

16. Monge, C.; Almodóvar, J.; Boudou, T.; Picart, C. Spatio-Temporal Control of LbL Films for Biomedical Applications: From 2D to 3D. Adv. Healthc. Mater. 2015, 4, 811-830. [CrossRef]

17. Li, M.; Ai, H.; Mills, D.K.; Lvov, Y.M.; McShane, M.J.; Gale, B.K. Using microfabrication and electrostatic layer-by-layer (LbL) sel-assembly technologies to improve the growth and alignment of smooth muscle cells. In Proceedings of the 2nd Annual International IEEE-EMBS Special Topic Conference on Microtechnologies in Medicine and Biology, Madison, WI, USA, 2-4 May 2002. [CrossRef]

18. Hiraoka, R.; Funasaki, Y.; Ishii, J.; Maruyama, T. Rational design of a degradable polyanion for layer-by-layer assembly for encapsulation and release of cationic functional biomolecules. Chem. Commun. 2015, 51, 17447-17450. [CrossRef]

19. Diaspro, A.; Silvano, D.; Krol, S.; Cavalleri, O.; Gliozzi, A. Single living cell encapsulation in nano-organized polyelectrolyte shells. Langmuir 2002, 18, 5047-5050. [CrossRef]

20. Mansouri, S.; Fatisson, J.; Miao, Z.; Merhi, Y.; Winnik, F.o.M.; Tabrizian, M. Silencing Red Blood Cell Recognition toward Anti-A Antibody by Means of Polyelectrolyte Layer-by-Layer Assembly in a Two-Dimensional Model System. Langmuir 2009, 25, 14071-14078. [CrossRef]

21. Balkundi, S.S.; Veerabadran, N.G.; Eby, D.M.; Johnson, G.R.; Lvov, Y.M. Encapsulation of Bacterial Spores in Nanoorganized Polyelectrolyte Shells. Langmuir 2009, 25, 14011-14016. [CrossRef]

22. Li, W.; Guan, T.; Zhang, X.; Wang, Z.; Wang, M.; Zhong, W.; Feng, H.; Xing, M.; Kong, J. The Effect of Layer-by-Layer Assembly Coating on the Proliferation and Differentiation of Neural Stem Cells. ACS Appl. Mater. Interfaces 2015, 7, 3018-3029. [CrossRef] [PubMed]

23. Lin, B.-j.; Wang, J.; Miao, Y.; Liu, Y.-q.; Jiang, W.; Fan, Z.-X.; Darabi, M.-A.; Hu, Z.-q.; Xing, M. Cytokine loaded layer-by-layer ultrathin matrices to deliver single dermal papilla cells for spot-by-spot hair follicle regeneration. J. Mater. Chem. B 2016, 4 , 489-504. [CrossRef] [PubMed]

24. Kearney, C.J.; Skaat, H.; Kennedy, S.M.; Hu, J.; Darnell, M.; Raimondo, T.M.; Mooney, D.J. Switchable release of entrapped nanoparticles from alginate hydrogels. Adv. Healthc. Mater. 2015, 4, 1634-1639. [CrossRef] [PubMed]

25. Oh, B.; Swaminathan, V.; Malkovskiy, A.; Santhanam, S.; McConnell, K.; George, P.M. Single-Cell Encapsulation via ClickChemistry Alters Production of Paracrine Factors from Neural Progenitor Cells. Adv. Sci. 2020, 7, 1902573. [CrossRef] [PubMed]

26. Kleinberger, R.M.; Burke, N.A.; Zhou, C.; Stöver, H.D. Synthetic polycations with controlled charge density and molecular weight as building blocks for biomaterials. J. Biomater. Sci. Polym. Ed. 2016, 27, 351-369. [CrossRef] [PubMed]

27. Ivashkov, O.V.; Sybachin, A.V.; Efimova, A.A.; Pergushov, D.V.; Orlov, V.N.; Schmalz, H.; Yaroslavov, A.A. The Influence of the Chain Length of Polycations on their Complexation with Anionic Liposomes. Chemphyschem 2015, 16, 2849-2853. [CrossRef]

28. Kulikov, S.; Khairullin, R.; Varlamov, V. Influence of polycations on antibacterial activity of lysostaphin. Appl. Biochem. Microbiol. 2015, 51, 683-687. [CrossRef]

29. Qiu, F.; Becker, K.W.; Knight, F.C.; Baljon, J.J.; Sevimli, S.; Shae, D.; Gilchuk, P.; Joyce, S.; Wilson, J.T. Poly(propylacrylic acid)peptide nanoplexes as a platform for enhancing the immunogenicity of neoantigen cancer vaccines. Biomaterials 2018, 182, 82-91. [CrossRef]

30. Kryger, M.B.; Pedersen, S.L.; Wohl, B.M.; Zelikin, A.N. Tools of gene transfer applied to the intracellular delivery of non-nucleic acid polyanionic drugs. Chem. Commun. 2016, 52, 889-891. [CrossRef]

31. La, C.C.; Takeuchi, L.E.; Abbina, S.; Vappala, S.; Abbasi, U.; Kizhakkedathu, J.N. Targeting Biological Polyanions in Blood: Strategies toward the Design of Therapeutics. Biomacromolecules 2020, 21, 2595-2621. [CrossRef]

32. Wang, X.; Niu, D.; Hu, C.; Li, P. Polyethyleneimine-based nanocarriers for gene delivery. Curr. Pharm. Des. 2015, 21, 6140-6156. [CrossRef] [PubMed]

33. Liu, H.W.; Hu, Y.; Ren, Y.; Nam, H.; Santos, J.L.; Ng, S.; Gong, L.; Brummet, M.; Carrington, C.A.; Ullman, C.G.; et al. Scalable Purification of Plasmid DNA Nanoparticles by Tangential Flow Filtration for Systemic Delivery. ACS Appl. Mater. Interfaces 2021, 13, 30326-30336. [CrossRef] [PubMed] 
34. Hou, X.; Shou, C.; He, M.; Xu, J.; Cheng, Y.; Yuan, Z.; Lan, M.; Zhao, Y.; Yang, Y.; Chen, X.; et al. A combination of LightOn gene expression system and tumor microenvironment-responsive nanoparticle delivery system for targeted breast cancer therapy. Acta Pharm. Sin. B 2020, 10, 1741-1753. [CrossRef]

35. Sedlacek, O.; Janouskova, O.; Verbraeken, B.; Hoogenboom, R. Straightforward Route to Superhydrophilic Poly(2-oxazoline)s via Acylation of Well-Defined Polyethylenimine. Biomacromolecules 2019, 20, 222-230. [CrossRef]

36. Yang, C.; Cheng, W.; Teo, P.Y.; Engler, A.C.; Coady, D.J.; Hedrick, J.L.; Yang, Y.Y. Mitigated Cytotoxicity and Tremendously Enhanced Gene Transfection Efficiency of PEI through Facile One-Step Carbamate Modification. Adv. Healthc. Mater. 2013, 2, 1304-1308. [CrossRef] [PubMed]

37. Zheng, G.; Zheng, J.; Xiao, L.; Shang, T.; Cai, Y.; Li, Y.; Xu, Y.; Chen, X.; Liu, Y.; Yang, B. Construction of a Phenylboronic AcidFunctionalized Nano-Prodrug for pH-Responsive Emodin Delivery and Antibacterial Activity. ACS omega 2021, 6, 8672-8679. [CrossRef] [PubMed]

38. Kozlovskaya, V.; Harbaugh, S.; Drachuk, I.; Shchepelina, O.; Kelley-Loughnane, N.; Stone, M.; Tsukruk, V.V. Hydrogen-bonded LbL shells for living cell surface engineering. Soft Matter 2011, 7, 2364-2372. [CrossRef]

39. Dalchand, N.; Doğangün, M.; Ohno, P.E.; Ma, E.; Martinson, A.B.F.; Geiger, F.M. Perturbation of Hydrogen-Bonding Networks over Supported Lipid Bilayers by Poly(allylamine hydrochloride). J. Phys. Chem. B 2019, 123, 4251-4257. [CrossRef]

40. Krol, S.; Nolte, M.; Diaspro, A.; Mazza, D.; Magrassi, R.; Gliozzi, A.; Fery, A. Encapsulated living cells on microstructured surfaces Langmuir 2005, 21, 705-709. [CrossRef]

41. Konnova, S.A.; Sharipova, I.R.; Demina, T.A.; Osin, Y.N.; Yarullina, D.R.; Ilinskaya, O.N.; Lvov, Y.M.; Fakhrullin, R.F. Biomimetic cell-mediated three-dimensional assembly of halloysite nanotubes. Chem. Commun. 2013, 49, 4208-4210. [CrossRef]

42. Wandrey, C.; Hernandez-Barajas, J.; Hunkeler, D. Diallyldimethylammonium chloride and its polymers. In Radical Polymerisation Polyelectrolytes; Springer: Berlin/Heidelberg, Germany, 1999; pp. 123-183.

43. Franz, B.; Balkundi, S.S.; Dahl, C.; Lvov, Y.M.; Prange, A. Layer-by-Layer Nano-Encapsulation of Microbes: Controlled Cell Surface Modification and Investigation of Substrate Uptake in Bacteria. Macromol. Biosci. 2010, 10, 164-172. [CrossRef] [PubMed]

44. Zhang, Z.; Li, Q.; Han, L.; Zhong, Y. Layer-by-layer films assembled from natural polymers for sustained release of neurotrophin Biomed. Mater. 2015, 10, 055006. [CrossRef] [PubMed]

45. Lee, H.; Kim, N.; Rheem, H.B.; Kim, B.J.; Park, J.H.; Choi, I.S. A Decade of Advances in Single-Cell Nanocoating for Mammalian Cells. Adv. Healthc. Mater. 2021, 10, e2100347. [CrossRef] [PubMed]

46. Bello, A.B.; Kim, D.; Kim, D.; Park, H.; Lee, S.H. Engineering and Functionalization of Gelatin Biomaterials: From Cell Culture to Medical Applications. Tissue Eng. Part B Rev. 2020, 26, 164-180. [CrossRef]

47. Echave, M.C.; Hernáez-Moya, R.; Iturriaga, L.; Pedraz, J.L.; Lakshminarayanan, R.; Dolatshahi-Pirouz, A.; Taebnia, N.; Orive, G. Recent advances in gelatin-based therapeutics. Expert Opin. Biol. Ther. 2019, 19, 773-779. [CrossRef]

48. Li, W.; Zhang, G.; Guan, T.; Zhang, X.; Khosrozadeh, A.; Xing, M.; Kong, J. Manipulable Permeability of Nanogel Encapsulation on Cells Exerts Protective Effect against TNF- $\alpha$-Induced Apoptosis. ACS Biomater. Sci. Eng. 2018, 4, 2825-2835. [CrossRef]

49. Liu, D.; Nikoo, M.; Boran, G.; Zhou, P.; Regenstein, J.M. Collagen and gelatin. Annu. Rev. Food Sci. Technol. 2015, 6, 527-557. [CrossRef]

50. Li, H.; Tan, Y.J.; Liu, S.; Li, L. Three-Dimensional Bioprinting of Oppositely Charged Hydrogels with Super Strong Interface Bonding. ACS Appl. Mater. Interfaces 2018, 10, 11164-11174. [CrossRef]

51. Bangar, S.P.; Whiteside, W.S. Nano-cellulose reinforced starch bio composite films- A review on green composites. Int. J. Biol. Macromol. 2021, 185, 849-860. [CrossRef]

52. Yu, Y.; Tyrikos-Ergas, T.; Zhu, Y.; Fittolani, G.; Bordoni, V.; Singhal, A.; Fair, R.J.; Grafmüller, A.; Seeberger, P.H.; Delbianco, M Systematic Hydrogen-Bond Manipulations To Establish Polysaccharide Structure-Property Correlations. Angew. Chem. Int. Ed. Engl. 2019, 58, 13127-13132. [CrossRef]

53. Kaldéus, T.; Träger, A.; Berglund, L.A.; Malmström, E.; Lo Re, G. Molecular Engineering of the Cellulose-Poly(Caprolactone) Bio-Nanocomposite Interface by Reactive Amphiphilic Copolymer Nanoparticles. ACS Nano 2019, 13, 6409-6420. [CrossRef]

54. Long, W.; Ouyang, H.; Zhou, C.; Wan, W.; Yu, S.; Qian, K.; Liu, M.; Zhang, X.; Feng, Y.; Wei, Y. Simultaneous surface functionalization and drug loading: A novel method for fabrication of cellulose nanocrystals-based $\mathrm{pH}$ responsive drug delivery system. Int. J. Biol. Macromol. 2021, 182, 2066-2075. [CrossRef] [PubMed]

55. Carlsson, L.; Fall, A.; Chaduc, I.; Wågberg, L.; Charleux, B.; Malmström, E.; D’Agosto, F.; Lansalot, M.; Carlmark, A. Modification of cellulose model surfaces by cationic polymer latexes prepared by RAFT-mediated surfactant-free emulsion polymerization. Polym. Chem. 2014, 5, 6076-6086. [CrossRef]

56. Singh, P.; Medronho, B.; Alves, L.; da Silva, G.J.; Miguel, M.G.; Lindman, B. Development of carboxymethyl cellulose-chitosan hybrid micro- and macroparticles for encapsulation of probiotic bacteria. Carbohydr. Polym. 2017, 175, 87-95. [CrossRef] [PubMed]

57. Velasco-Mallorquí, F.; Rodríguez-Comas, J.; Ramón-Azcón, J. Cellulose-based scaffolds enhance pseudoislets formation and functionality. Biofabrication 2021, 13, 035044. [CrossRef] [PubMed]

58. Prochorov, A.; Tretjak, S.; Goranov, V.; Glinnik, A.; Goltsev, M. Treatment of insulin dependent diabetes mellitus with intravascular transplantation of pancreatic islet cells without immunosuppressive therapy. Adv. Med. Sci. 2008, 53, 240. [CrossRef] [PubMed]

59. Moradian, C.; Rahbarizadeh, F. PE38-based gene therapy of HER2-positive breast cancer stem cells via VHH-redirected polyamidoamine dendrimers. Sci. Rep. 2021, 11, 15517. [CrossRef] 
60. Qi, X.; Qin, J.; Fan, Y.; Qin, X.; Jiang, Y.; Wu, Z. Carboxymethyl Chitosan-Modified Polyamidoamine Dendrimer Enables Progressive Drug Targeting of Tumors via pH-Sensitive Charge Inversion. J. Biomed. Nanotechnol. 2016, 12, 667-678. [CrossRef]

61. Urbán, P.; Ranucci, E.; Fernàndez-Busquets, X. Polyamidoamine nanoparticles as nanocarriers for the drug delivery to malaria parasite stages in the mosquito vector. Nanomedicine 2015, 10, 3401-3414. [CrossRef]

62. Frost, R.; Coué, G.; Engbersen, J.F.; Zäch, M.; Kasemo, B.; Svedhem, S. Bioreducible insulin-loaded nanoparticles and their interaction with model lipid membranes. J. Colloid Interface Sci. 2011, 362, 575-583. [CrossRef]

63. Gattás-Asfura, K.M.; Stabler, C.L. Bioorthogonal layer-by-layer encapsulation of pancreatic islets via hyperbranched polymers ACS Appl. Mater. Interfaces 2013, 5, 9964-9974. [CrossRef] [PubMed]

64. Azmana, M.; Mahmood, S.; Hilles, A.R.; Rahman, A.; Arifin, M.A.B.; Ahmed, S. A review on chitosan and chitosan-based bionanocomposites: Promising material for combatting global issues and its applications. Int. J. Biol. Macromol. 2021, 185, 832-848. [CrossRef]

65. Hu, B.; Guo, Y.; Li, H.; Liu, X.; Fu, Y.; Ding, F. Recent advances in chitosan-based layer-by-layer biomaterials and their biomedical applications. Carbohydr. Polym. 2021, 271, 118427. [CrossRef] [PubMed]

66. Patrulea, V.; Hirt-Burri, N.; Jeannerat, A.; Applegate, L.A.; Ostafe, V.; Jordan, O.; Borchard, G. Peptide-decorated chitosan derivatives enhance fibroblast adhesion and proliferation in wound healing. Carbohydr. Polym. 2016, 142, 114-123. [CrossRef]

67. Li, L.; Zhao, F.; Zhao, B.; Zhang, J.; Li, C.; Qiao, R. Chitosan Grafted with Phosphorylcholine and Macrocyclic Polyamine as an Effective Gene Delivery Vector: Preparation, Characterization and In Vitro Transfection. Macromol. Biosci. 2015, 15, 912-926. [CrossRef] [PubMed]

68. Pei, L.; Cai, Z.; Shang, S.; Song, Z. Synthesis and antibacterial activity of alkylated chitosan under basic ionic liquid conditions J. Appl. Polym. Sci. 2014, 131. [CrossRef]

69. Facchi, S.P.; Scariot, D.B.; Bueno, P.V.; Souza, P.R.; Figueiredo, L.C.; Follmann, H.D.; Nunes, C.S.; Monteiro, J.P.; Bonafé, E.G.; Nakamura, C.V. Preparation and cytotoxicity of N-modified chitosan nanoparticles applied in curcumin delivery. Int. J. Biol. Macromol. 2016, 87, 237-245. [CrossRef]

70. Torabi, S.; Mahdavian, A.R.; Sanei, M.; Abdollahi, A. Chitosan and functionalized acrylic nanoparticles as the precursor of new generation of bio-based antibacterial films. Mater. Sci. Eng. C 2016, 59, 1-9. [CrossRef]

71. Beidokhti, H.R.N.; Ghaffarzadegan, R.; Mirzakhanlouei, S.; Ghazizadeh, L.; Dorkoosh, F.A. Preparation, Characterization, and Optimization of Folic Acid-Chitosan-Methotrexate Core-Shell Nanoparticles by Box-Behnken Design for Tumor-Targeted Drug Delivery. AAPS PharmSciTech 2017, 18, 115-129. [CrossRef]

72. Liang, H.; Li, J.; He, Y.; Xu, W.; Liu, S.; Li, Y.; Chen, Y.; Li, B. Engineering multifunctional films based on metal-phenolic networks for rational pH-responsive delivery and cell imaging. ACS Biomater. Sci. Eng. 2016, 2, 317-325. [CrossRef]

73. Mekhail, M.; Jahan, K.; Tabrizian, M. Genipin-crosslinked chitosan/poly-L-lysine gels promote fibroblast adhesion and proliferation. Carbohydr. Polym. 2014, 108, 91-98. [CrossRef] [PubMed]

74. Kanczler, J.M.; Sura, H.S.; Magnay, J.; Green, D.; Oreffo, R.O.; Dobson, J.P.; El Haj, A.J. Controlled differentiation of human bone marrow stromal cells using magnetic nanoparticle technology. Tissue Eng. Part A 2010, 16, 3241-3250. [CrossRef] [PubMed]

75. Karabıyık Acar, Ö.; Bedir, S.; Kayitmazer, A.B.; Kose, G.T. Chondro-inductive hyaluronic acid/chitosan coacervate-based scaffolds for cartilage tissue engineering. Int. J. Biol. Macromol. 2021, 188, 300-312. [CrossRef]

76. Kim, M.J.; Park, H.S.; Kim, J.W.; Lee, E.Y.; Rhee, M.; You, Y.H.; Khang, G.; Park, C.G.; Yoon, K.H. Suppression of Fibrotic Reactions of Chitosan-Alginate Microcapsules Containing Porcine Islets by Dexamethasone Surface Coating. Endocrinol. Metab. 2021, 36, 146-156. [CrossRef]

77. Zhu, J.-H.; Wang, X.-W.; Ng, S.; Quek, C.-H.; Ho, H.-T.; Lao, X.-J.; Yu, H. Encapsulating live cells with water-soluble chitosan in physiological conditions. J. Biotechnol. 2005, 117, 355-365. [CrossRef]

78. Chen, S.; Huang, S.; Li, Y.; Zhou, C. Recent Advances in Epsilon-Poly-L-Lysine and L-Lysine-Based Dendrimer Synthesis, Modification, and Biomedical Applications. Front. Chem. 2021, 9, 659304. [CrossRef] [PubMed]

79. Samal, S.K.; Dash, M.; Van Vlierberghe, S.; Kaplan, D.L.; Chiellini, E.; van Blitterswijk, C.; Moroni, L.; Dubruel, P. Cationic polymers and their therapeutic potential. Chem. Soc. Rev. 2012, 41, 7147-7194. [CrossRef] [PubMed]

80. Dai, J.; Zou, S.; Pei, Y.; Cheng, D.; Ai, H.; Shuai, X. Polyethylenimine-grafted copolymer of poly(l-lysine) and poly(ethylene glycol) for gene delivery. Biomaterials 2011, 32, 1694-1705. [CrossRef]

81. Wu, T.; Wang, L.; Ding, S.; You, Y. Fluorinated PEG-Polypeptide Polyplex Micelles Have Good Serum-Resistance and Low Cytotoxicity for Gene Delivery. Macromol. Biosci. 2017, 17, 1700114. [CrossRef]

82. Jing, H.; Cheng, W.; Zhang, J.-W.; Han, X.; Shao, H.; Sun, Y.-X. Galactosylated poly-L-lysine targeted microbubbles for ultrasound mediated antisense c-myc gene transfection in hepatocellular carcinoma cells. Arch. Med. Sci. AMS 2015, 11, 292. [CrossRef]

83. Zhou, Z.; Tang, J.; Sun, Q.; Murdoch, W.J.; Shen, Y. A multifunctional PEG-PLL drug conjugate forming redox-responsive nanoparticles for intracellular drug delivery. J. Mater. Chem. B 2015, 3, 7594-7603. [CrossRef] [PubMed]

84. Franiak-Pietryga, I.; Maciejewski, H.; Ostrowska, K.; Appelhans, D.; Voit, B.; Misiewicz, M.; Kowalczyk, P.; Bryszewska, M.; Borowiec, M. Dendrimer-based nanoparticles for potential personalized therapy in chronic lymphocytic leukemia: Targeting the BCR-Signaling Pathway. Int. J. Biol. Macromol. 2016, 88, 156-161. [CrossRef] [PubMed]

85. Myung, J.H.; Hsu, H.J.; Bugno, J.; Tam, K.A.; Hong, S. Chemical Structure and Surface Modification of Dendritic Nanomaterials Tailored for Therapeutic and Diagnostic Applications. Curr. Top. Med. Chem. 2017, 17, 1542-1554. [CrossRef] [PubMed] 
86. Lam, J.; Clark, E.C.; Fong, E.L.; Lee, E.J.; Lu, S.; Tabata, Y.; Mikos, A.G. Evaluation of cell-laden polyelectrolyte hydrogels incorporating poly (1-Lysine) for applications in cartilage tissue engineering. Biomaterials 2016, 83, 332-346. [CrossRef] [PubMed]

87. Veerabadran, N.G.; Goli, P.L.; Stewart-Clark, S.S.; Lvov, Y.M.; Mills, D.K. Nanoencapsulation of stem cells within polyelectrolyte multilayer shells. Macromol. Biosci. 2007, 7, 877-882. [CrossRef] [PubMed]

88. Wilson, J.T.; Cui, W.; Chaikof, E.L. Layer-by-layer assembly of a conformal nanothin PEG coating for intraportal islet transplantation. Nano Lett. 2008, 8, 1940-1948. [CrossRef]

89. Xu, F.; Wang, P.; Zhang, Y.Z.; Chen, X.L. Diversity of Three-Dimensional Structures and Catalytic Mechanisms of Alginate Lyases. Appl. Environ. Microbiol. 2018, 84, e02040-17. [CrossRef]

90. Hu, C.; Lu, W.; Mata, A.; Nishinari, K.; Fang, Y. Ions-induced gelation of alginate: Mechanisms and applications. Int. J. Biol. Macromol. 2021, 177, 578-588. [CrossRef]

91. Virumbrales-Muñoz, M.; Paz-Artigas, L.; Ciriza, J.; Alcaine, C.; Espona-Noguera, A.; Doblaré, M.; Sáenz Del Burgo, L.; Ziani, K.; Pedraz, J.L.; Fernández, L.; et al. Force Spectroscopy Imaging and Constriction Assays Reveal the Effects of Graphene Oxide on the Mechanical Properties of Alginate Microcapsules. ACS Biomater. Sci. Eng. 2021, 7, 242-253. [CrossRef]

92. Vos, P.d.; Andersson, A.; Tam, S.; Faas, M.; Halle, J. Advances and barriers in mammalian cell encapsulation for treatment of diabetes. Immunol. Endocr. Metab. Agents Med. Chem. 2006, 6, 139-153. [CrossRef]

93. Kong, D.; Xu, H.; Chen, M.; Yu, Y.; Qian, Y.; Qin, T.; Tong, Y.; Xia, Q.; Hang, H. Co-encapsulation of HNF4 $\alpha$ overexpressing UMSCs and human primary hepatocytes ameliorates mouse acute liver failure. Stem Cell. Res. Ther. 2020, 11, 449. [CrossRef] [PubMed]

94. Ørning, P.; Hoem, K.S.; Coron, A.E.; Skjåk-Bræk, G.; Mollnes, T.E.; Brekke, O.L.; Espevik, T.; Rokstad, A.M. Alginate microsphere compositions dictate different mechanisms of complement activation with consequences for cytokine release and leukocyte activation. J. Control. Release 2016, 229, 58-69. [CrossRef] [PubMed]

95. Spasojevic, M.; Bhujbal, S.; Paredes, G.; Haan, B.J.; Schouten, A.J.; Vos, P. Considerations in binding diblock copolymers on hydrophilic alginate beads for providing an immunoprotective membrane. J. Biomed. Mater. Res. Part A 2014, 102, 1887-1896. [CrossRef] [PubMed]

96. Charbonier, F.; Indana, D.; Chaudhuri, O. Tuning Viscoelasticity in Alginate Hydrogels for 3D Cell Culture Studies. Curr. Protoc. 2021, 1, e124. [CrossRef]

97. Fang, Y.; Liu, Q.; Zhu, S. Selective biosorption mechanism of methylene blue by a novel and reusable sugar beet pulp cellulose/sodium alginate/iron hydroxide composite hydrogel. Int. J. Biol. Macromol. 2021, 188, 993-1002. [CrossRef]

98. Kendall, W.F., Jr.; Opara, E.C. Polymeric Materials for Perm-Selective Coating of Alginate Microbeads. Methods Mol. Biol. 2017, 1479, 95-109. [CrossRef]

99. Elsayed, N.H.; Monier, M.; Alatawi, R.A. Synthesis and characterization of photo-crosslinkable 4-styryl-pyridine modified alginate. Carbohydr. Polym. 2016, 145, 121-131. [CrossRef]

100. Popescu, I.; Turtoi, M.; Suflet, D.M.; Dinu, M.V.; Darie-Nita, R.N.; Anghelache, M.; Calin, M.; Constantin, M. Alginate/poloxamer hydrogel obtained by thiol-acrylate photopolymerization for the alleviation of the inflammatory response of human keratinocytes. Int. J. Biol. Macromol. 2021, 180, 418-431. [CrossRef]

101. Genç, H.; Hazur, J.; Karakaya, E.; Dietel, B.; Bider, F.; Groll, J.; Alexiou, C.; Boccaccini, A.R.; Detsch, R.; Cicha, I. Differential Responses to Bioink-Induced Oxidative Stress in Endothelial Cells and Fibroblasts. Int. J. Mol. Sci. 2021, 22, 2358. [CrossRef]

102. Sondermeijer, H.P.; Witkowski, P.; Woodland, D.; Seki, T.; Aangenendt, F.J.; van der Laarse, A.; Itescu, S.; Hardy, M.A. Optimization of alginate purification using polyvinylidene difluoride membrane filtration: Effects on immunogenicity and biocompatibility of three-dimensional alginate scaffolds. J. Biomater. Appl. 2016, 31, 510-520. [CrossRef]

103. Kumar, S.; Ingle, H.; Prasad, D.V.R.; Kumar, H. Recognition of bacterial infection by innate immune sensors. Crit. Rev. Microbiol. 2013, 39, 229-246. [CrossRef] [PubMed]

104. Valachová, K.; Šoltés, L. Hyaluronan as a Prominent Biomolecule with Numerous Applications in Medicine. Int. J. Mol. Sci. 2021, 22, 7077. [CrossRef] [PubMed]

105. Lam, J.; Truong, N.F.; Segura, T. Design of cell-matrix interactions in hyaluronic acid hydrogel scaffolds. Acta Biomater. 2014, 10, 1571-1580. [CrossRef] [PubMed]

106. Zhang, M.; Yang, J.; Deng, F.; Guo, C.; Yang, Q.; Wu, H.; Ni, Y.; Huang, L.; Chen, L.; Ding, C. Dual-functionalized hyaluronic acid as a facile modifier to prepare polyanionic collagen. Carbohydr. Polym. 2019, 215, 358-365. [CrossRef]

107. Schanté, C.E.; Zuber, G.; Herlin, C.; Vandamme, T.F. Chemical modifications of hyaluronic acid for the synthesis of derivatives for a broad range of biomedical applications. Carbohydr. Polym. 2011, 85, 469-489. [CrossRef]

108. Grewal, M.G.; Gray, V.P.; Letteri, R.A.; Highley, C.B. User-defined, temporal presentation of bioactive molecules on hydrogel substrates using supramolecular coiled coil complexes. Biomater. Sci. 2021, 9, 4374-4387. [CrossRef]

109. Khoshakhlagh, P.; Moore, M.J. Photoreactive interpenetrating network of hyaluronic acid and Puramatrix as a selectively tunable scaffold for neurite growth. Acta Biomater. 2015, 16, 23-34. [CrossRef]

110. Kim, M.; Erickson, I.E.; Huang, A.H.; Garrity, S.T.; Mauck, R.L.; Steinberg, D.R. Donor Variation and Optimization of Human Mesenchymal Stem Cell Chondrogenesis in Hyaluronic Acid. Tissue Eng. Part A 2018, 24, 1693-1703. [CrossRef]

111. Liu, Y.; Hsu, Y.H.; Huang, A.P.; Hsu, S.H. Semi-Interpenetrating Polymer Network of Hyaluronan and Chitosan Self-Healing Hydrogels for Central Nervous System Repair. ACS Appl. Mater. Interfaces 2020, 12, 40108-40120. [CrossRef] 
112. Harel, Z.; Harel, S.; Shah, P.S.; Wald, R.; Perl, J.; Bell, C.M. Gastrointestinal adverse events with sodium polystyrene sulfonate (Kayexalate) use: A systematic review. Am. J. Med. 2013, 126, 9-24. [CrossRef]

113. Choi, W.S.; Choi, I.S.; Lee, J.K.; Yoon, K.R. Preparation of fluorescein-functionalized electrospun fibers coated with TiO2 and gold nanoparticles for visible-light-induced photocatalysis. Mater. Chem. Phys. 2015, 163, 213-218. [CrossRef]

114. Åkerfeldt, M.; Nilsson, E.; Gillgard, P.; Walkenström, P. Textile piezoelectric sensors-melt spun bi-component poly (vinylidene fluoride) fibres with conductive cores and poly (3,4-ethylene dioxythiophene)-poly (styrene sulfonate) coating as the outer electrode. Fash. Text. 2014, 1, 1-17. [CrossRef]

115. Murakami, Y.; Iwata, H.; Kitano, E.; Kitamura, H.; Ikada, Y. Interaction of poly(styrene sulfonic acid) with the classical pathway of the serum complement system. J. Biomater. Sci. Polym. Ed. 2005, 16, 685-697. [CrossRef]

116. Fakhrullin, R.F.; Zamaleeva, A.I.; Morozov, M.V.; Tazetdinova, D.I.; Alimova, F.K.; Hilmutdinov, A.K.; Zhdanov, R.I.; Kahraman, M.; Culha, M. Living fungi cells encapsulated in polyelectrolyte shells doped with metal nanoparticles. Langmuir 2009, 25, 4628-4634. [CrossRef] [PubMed]

117. Pandey, A.; Chouhan, R.S.; Gurbuz, Y.; Niazi, J.H.; Qureshi, A.S. cerevisiae whole-cell based capacitive biochip for the detection of toxicity of different forms of carbon nanotubes. Sens. Actuators B Chem. 2015, 218, 253-260. [CrossRef]

118. Yang, X.-N.; Xue, D.-D.; Li, J.-Y.; Liu, M.; Jia, S.-R.; Chu, L.-Q.; Wahid, F.; Zhang, Y.-M.; Zhong, C. Improvement of antimicrobial activity of graphene oxide/bacterial cellulose nanocomposites through the electrostatic modification. Carbohydr. Polym. 2016, 136, 1152-1160. [CrossRef] [PubMed]

119. Konnova, S.A.; Lvov, Y.M.; Fakhrullin, R.F. Nanoshell Assembly for Magnet-Responsive Oil-Degrading Bacteria. Langmuir 2016, 32, 12552-12558. [CrossRef] [PubMed]

120. Gorobets, S.; Gorobets, O.Y.; Demianenko, I.; Nikolaenko, R. Self-organization of magnetite nanoparticles in providing Saccharomyces cerevisiae Yeasts with magnetic properties. J. Magn. Magn. Mater. 2013, 337, 53-57. [CrossRef]

121. Fakhrullin, R.F.; García-Alonso, J.; Paunov, V.N. A direct technique for preparation of magnetically functionalised living yeast cells. Soft Matter 2010, 6, 391-397. [CrossRef]

122. Dzamukova, M.R.; Zamaleeva, A.I.; Ishmuchametova, D.G.; Osin, Y.N.; Kiyasov, A.P.; Nurgaliev, D.K.; Ilinskaya, O.N.; Fakhrullin, R.F. A direct technique for magnetic functionalization of living human cells. Langmuir 2011, 27, 14386-14393. [CrossRef]

123. Gal, N.; Massalha, S.; Samuelly-Nafta, O.; Weihs, D. Effects of particle uptake, encapsulation, and localization in cancer cells on intracellular applications. Med. Eng. Phys. 2015, 37, 478-483. [CrossRef] [PubMed]

124. Yang, S.H.; Kang, S.M.; Lee, K.-B.; Chung, T.D.; Lee, H.; Choi, I.S. Mussel-inspired encapsulation and functionalization of individual yeast cells. J. Am. Chem. Soc. 2011, 133, 2795-2797. [CrossRef] [PubMed]

125. Zhou, T.; Yan, L.; Xie, C.; Li, P.; Jiang, L.; Fang, J.; Zhao, C.; Ren, F.; Wang, K.; Wang, Y.; et al. A Mussel-Inspired Persistent ROS-Scavenging, Electroactive, and Osteoinductive Scaffold Based on Electrochemical-Driven In Situ Nanoassembly. Small 2019, 15, e1805440. [CrossRef]

126. Gao, T.; Chen, T.; Feng, C.; He, X.; Mu, C.; Anzai, J.I.; Li, G. Design and fabrication of flexible DNA polymer cocoons to encapsulate live cells. Nat. Commun. 2019, 10, 2946. [CrossRef] [PubMed]

127. Qureshi, S.S.; Zheng, Z.; Sarwar, M.I.; Félix, O.; Decher, G. Nanoprotective layer-by-layer coatings with epoxy components for enhancing abrasion resistance: Toward robust multimaterial nanoscale films. ACS Nano 2013, 7, 9336-9344. [CrossRef] [PubMed]

128. Gutiérrez-Pineda, E.; Andreozzi, P.; Diamanti, E.; Anguiano, R.; Ziolo, R.F.; Moya, S.E.; José Rodríguez-Presa, M.; Gervasi, C.A Effects of valinomycin doping on the electrical and structural properties of planar lipid bilayers supported on polyelectrolyte multilayers. Bioelectrochemistry 2021, 138, 107688. [CrossRef] [PubMed]

129. Kékicheff, P.; Schneider, G.F.; Decher, G. Size-controlled polyelectrolyte complexes: Direct measurement of the balance of forces involved in the triggered collapse of layer-by-layer assembled nanocapsules. Langmuir 2013, 29, 10713-10726. [CrossRef]

130. Tezel, G.B.; Arole, K.; Holta, D.E.; Radovic, M.; Green, M.J. Interparticle interactions and rheological signatures of Ti(3)C(2)T(z) MXene dispersions. J. Colloid Interface Sci. 2021, 605, 120-128. [CrossRef]

131. Frank, C.; Novak, J.; Banerjee, R.; Gerlach, A.; Schreiber, F.; Vorobiev, A.; Kowarik, S. Island size evolution and molecular diffusion during growth of organic thin films followed by time-resolved specular and off-specular scattering. Phys. Rev. B 2014, 90, 045410. [CrossRef]

132. Kim, B.; Kwon, S.; Lee, M.; Kim, Q.; An, S.; Jhe, W. Probing nonlinear rheology layer-by-layer in interfacial hydration water. Proc. Natl. Acad. Sci. USA 2015, 112, 15619-15623. [CrossRef]

133. Szilagyi, I.; Trefalt, G.; Tiraferri, A.; Maroni, P.; Borkovec, M. Polyelectrolyte adsorption, interparticle forces, and colloidal aggregation. Soft Matter 2014, 10, 2479-2502. [CrossRef] [PubMed]

134. Ariga, K.; Yamauchi, Y.; Rydzek, G.; Ji, Q.; Yonamine, Y.; Wu, K.C.-W.; Hill, J.P. Layer-by-layer nanoarchitectonics: Invention, innovation, and evolution. Chem. Lett. 2014, 43, 36-68. [CrossRef]

135. Kargl, R.; Mohan, T.; Bracic, M.; Kulterer, M.; Doliška, A.; Stana-Kleinschek, K.; Ribitsch, V. Adsorption of carboxymethyl cellulose on polymer surfaces: Evidence of a specific interaction with cellulose. Langmuir 2012, 28, 11440-11447. [CrossRef] [PubMed]

136. Li, Y.; Wang, X.; Sun, J. Layer-by-layer assembly for rapid fabrication of thick polymeric films. Chem. Soc. Rev. 2012, 41, 5998-6009. [CrossRef] [PubMed]

137. Xiao, F.-X.; Miao, J.; Liu, B. Layer-by-layer self-assembly of CdS quantum dots/graphene nanosheets hybrid films for photoelectrochemical and photocatalytic applications. J. Am. Chem. Soc. 2014, 136, 1559-1569. [CrossRef] [PubMed] 
138. Mazilu, D.; Mazilu, I.; Seredinski, A.; Kim, V.; Simpson, B.; Banks, W. Cooperative sequential adsorption models on a Cayley tree: Analytical results and applications. J. Stat. Mech. Theory Exp. 2012, 2012, P09002. [CrossRef]

139. Wang, X.; Choi, S.-I.; Roling, L.T.; Luo, M.; Ma, C.; Zhang, L.; Chi, M.; Liu, J.; Xie, Z.; Herron, J.A. Palladium-platinum core-shell icosahedra with substantially enhanced activity and durability towards oxygen reduction. Nat. Commun. 2015, 6, 7594. [CrossRef]

140. Kuroda, Y.; Kuroda, K. Layer-by-layer assembly of imogolite nanotubes and polyelectrolytes into core-shell particles and their conversion to hierarchically porous spheres. Sci. Technol. Adv. Mater. 2008, 9, 025018. [CrossRef]

141. Mathivanan, N.; Paramasivam, G.; Vergaelen, M.; Rajendran, J.; Hoogenboom, R.; Sundaramurthy, A. Hydrogen-Bonded Multilayer Thin Films and Capsules Based on Poly(2-n-propyl-2-oxazoline) and Tannic Acid: Investigation on Intermolecular Forces, Stability, and Permeability. Langmuir 2019, 35, 14712-14724. [CrossRef]

142. Huang, J.; Ware, H.O.T.; Hai, R.; Shao, G.; Sun, C. Conformal Geometry and Multimaterial Additive Manufacturing through Freeform Transformation of Building Layers. Adv. Mater. 2021, 33, e2005672. [CrossRef]

143. Katagiri, K.; Yamazaki, S.-I.; Inumaru, K.; Koumoto, K. Anti-reflective coatings prepared via layer-by-layer assembly of mesoporous silica nanoparticles and polyelectrolytes. Polym. J. 2015, 47, 190-194. [CrossRef]

144. Sergeeva, Y.N.; Huang, T.; Felix, O.; Jung, L.; Tropel, P.; Viville, S.; Decher, G. What is really driving cell-surface interactions? Layerby-layer assembled films may help to answer questions concerning cell attachment and response to biomaterials. Biointerphases 2016, 11, 019009. [CrossRef] [PubMed]

145. Guzmán, E.; Rubio, R.G.; Ortega, F. A closer physico-chemical look to the Layer-by-Layer electrostatic self-assembly of polyelectrolyte multilayers. Adv. Colloid Interface Sci. 2020, 282, 102197. [CrossRef] [PubMed]

146. Vaterrodt, A.; Thallinger, B.; Daumann, K.; Koch, D.; Guebitz, G.M.; Ulbricht, M. Antifouling and antibacterial multi-functional polyzwitterion/enzyme coating on silicone catheter material prepared by electrostatic layer-by-layer assembly. Langmuir 2016, 32, 1347-1359. [CrossRef]

147. Xu, J.; Wang, Z.; Wen, L.; Zhou, X.; Xu, J.; Yang, S. Dynamics of the layer-by-layer assembly of a poly (acrylic acid)-lanthanide complex colloid and poly (diallyldimethyl ammonium). Soft Matter 2016, 12, 867-875. [CrossRef]

148. Selin, V.; Ankner, J.F.; Sukhishvili, S.A. Diffusional Response of Layer-by-Layer Assembled Polyelectrolyte Chains to Salt Annealing. Macromolecules 2015, 48, 3983-3990. [CrossRef]

149. Varga, I.; Mezei, A.; Mészáros, R.; Claesson, P.M. Controlling the interaction of poly (ethylene imine) adsorption layers with oppositely charged surfactant by tuning the structure of the preadsorbed polyelectrolyte layer. Soft Matter 2011, 7, 10701-10712 [CrossRef]

150. Popa, I.; Gillies, G.; Papastavrou, G.; Borkovec, M. Attractive and repulsive electrostatic forces between positively charged latex particles in the presence of anionic linear polyelectrolytes. J. Phys. Chem. B 2010, 114, 3170-3177. [CrossRef]

151. Bellanger, H.; Casdorff, K.; Muff, L.F.; Ammann, R.; Burgert, I.; Michen, B. Layer-by-layer deposition on a heterogeneous surface: Effect of sorption kinetics on the growth of polyelectrolyte multilayers. J. Colloid Interface Sci. 2017, 500, 133-141. [CrossRef]

152. Ciejka, J.; Grzybala, M.; Gut, A.; Szuwarzynski, M.; Pyrc, K.; Nowakowska, M.; Szczubiałka, K. Tuning the Surface Properties of Poly(Allylamine Hydrochloride)-Based Multilayer Films. Materials 2021, 14, 2361. [CrossRef]

153. Popa, I.; Papastavrou, G.; Borkovec, M. Charge regulation effects on electrostatic patch-charge attraction induced by adsorbed dendrimers. Phys. Chem. Chem. Phys. 2010, 12, 4863-4871. [CrossRef] [PubMed]

154. Yuan, W.; Weng, G.M.; Lipton, J.; Li, C.M.; Van Tassel, P.R.; Taylor, A.D. Weak polyelectrolyte-based multilayers via layer-by-layer assembly: Approaches, properties, and applications. Adv. Colloid Interface Sci. 2020, 282, 102200. [CrossRef] [PubMed]

155. Petrila, L.M.; Bucatariu, F.; Mihai, M.; Teodosiu, C. Polyelectrolyte Multilayers: An Overview on Fabrication, Properties, and Biomedical and Environmental Applications. Materials 2021, 14, 4152. [CrossRef] [PubMed]

156. Kang, S.; Pyo, J.B.; Kim, T.S. Layer-by-Layer Assembly of Free-Standing Nanofilms by Controlled Rolling. Langmuir 2018, 34, 5831-5836. [CrossRef]

157. Choi, D.; Heo, J.; Hong, J. Investigation of the Structural Mechanism and Film Growth on Cytoprotective Type I Collagen-Based Nanocoating of Individual Cellular Surfaces. Langmuir 2021, 37, 4587-4598. [CrossRef]

158. Min, L.; GAO, Y.; Hornicek, F.J.; Amiji, M.M.; Duan, Z. Abstract LB-102: Layer-by-layer engineering of upconversion nanoparticle based siRNA and miRNA delivery system for cancer therapy. Cancer Res. 2015, 75, LB-102. [CrossRef]

159. Batys, P.; Nosek, M.; Weroński, P. Structure analysis of layer-by-layer multilayer films of colloidal particles. Appl. Surf. Sci. 2015, 332, 318-327. [CrossRef]

160. Adamczyk, Z.; Zembala, M.; Michna, A. Polyelectrolyte adsorption layers studied by streaming potential and particle deposition. J. Colloid Interface Sci. 2006, 303, 353-364. [CrossRef]

161. Liu, C.; Shi, L.; Wang, R. Enhanced hollow fiber membrane performance via semi-dynamic layer-by-layer polyelectrolyte inner surface deposition for nanofiltration and forward osmosis applications. React. Funct. Polym. 2015, 86, 154-160. [CrossRef]

162. Bucur, C.B.; Lita, A.; Osada, N.; Muldoon, J. A soft, multilayered lithium-electrolyte interface. Energy Environ. Sci. 2016, 9 , 112-116. [CrossRef]

163. Fuller, M.; Köper, I. Polyelectrolyte-Coated Gold Nanoparticles: The Effect of Salt and Polyelectrolyte Concentration on Colloidal Stability. Polymers 2018, 10, 1336. [CrossRef] [PubMed]

164. Szilágyi, I.; Rosická, D.; Hierrezuelo, J.; Borkovec, M. Charging and stability of anionic latex particles in the presence of linear poly (ethylene imine). J. Colloid Interface Sci. 2011, 360, 580-585. [CrossRef] [PubMed] 
165. Ros, S.; Freitag, J.S.; Smith, D.M.; Stöver, H.D.H. Charge-Shifting Polycations Based on N,N-(dimethylamino)ethyl Acrylate for Improving Cytocompatibility During DNA Delivery. ACS Omega 2020, 5, 9114-9122. [CrossRef]

166. Cai, C.; Mao, S.; Kissel, T. O-013-Layer-by-layer nanostructured protein loaded nanoparticles: A feasibility study using lysozyme as model protein and chitosan as coating material. Asian J. Pharm. Sci. 2016, 1, 64-65. [CrossRef]

167. Richardson, J.J.; Tardy, B.L.; Ejima, H.; Guo, J.; Cui, J.; Liang, K.; Choi, G.H.; Yoo, P.J.; De Geest, B.G.; Caruso, F. Thermally Induced Charge Reversal of Layer-by-Layer Assembled Single-Component Polymer Films. ACS Appl. Mater. Interfaces 2016, 8, 7449-7455. [CrossRef] [PubMed]

168. Kim, H.O.; Lee, S.H.; Na, W.; Lim, J.W.; Park, G.; Park, C.; Lee, H.; Kang, A.; Haam, S.; Choi, I.; et al. Cell-mimic polymersomeshielded islets for long-term immune protection of neonatal porcine islet-like cell clusters. J. Mater. Chem. B 2020, 8, $2476-2482$. [CrossRef]

169. Carroll, L.; Mridha, A.R.; Tuch, B.E. Encapsulation and Transplantation of Pancreatic Progenitor Cells. Methods Mol. Biol. 2019, 2029, 93-102. [CrossRef]

170. Nguyen, T.D.; Guyot, S.; Lherminier, J.; Wache, Y.; Saurel, R.; Husson, F. Protection of living yeast cells by micro-organized shells of natural polyelectrolytes. Process Biochem. 2015, 50, 1528-1536. [CrossRef]

171. Yang, J.; Li, J.; Li, X.; Wang, X.; Yang, Y.; Kawazoe, N.; Chen, G. Nanoencapsulation of individual mammalian cells with cytoprotective polymer shell. Biomaterials 2017, 133, 253-262. [CrossRef]

172. González-Ferrero, C.; Irache, J.M.; Marín-Calvo, B.; Ortiz-Romero, L.; Virto-Resano, R.; González-Navarro, C.J. Encapsulation of probiotics in soybean protein-based microparticles preserves viable cell concentration in foods all along the production and storage processes. J. Microencapsul. 2020, 37, 242-253. [CrossRef]

173. Wang, G.; Wang, L.; Liu, P.; Yan, Y.; Xu, X.; Tang, R. Extracellular silica nanocoat confers thermotolerance on individual cells: A case study of material-based functionalization of living cells. ChemBioChem 2010, 11, 2368-2373. [CrossRef]

174. Yang, S.H.; Lee, K.B.; Kong, B.; Kim, J.H.; Kim, H.S.; Choi, I.S. Biomimetic encapsulation of individual cells with silica. Angew. Chem. Int. Ed. 2009, 48, 9160-9163. [CrossRef] [PubMed]

175. Kempaiah, R.; Salgado, S.; Chung, W.L.; Maheshwari, V. Graphene as membrane for encapsulation of yeast cells: Protective and electrically conducting. Chem. Commun. 2011, 47, 11480-11482. [CrossRef] [PubMed]

176. Kang, Y.; Georgiou, A.I.; MacFarlane, R.J.; Klontzas, M.E.; Heliotis, M.; Tsiridis, E.; Mantalaris, A. Fibronectin stimulates the osteogenic differentiation of murine embryonic stem cells. J. Tissue Eng. Regen. Med. 2015. [CrossRef] [PubMed]

177. Aikawa, T.; Konno, T.; Ishihara, K. Phospholipid polymer hydrogel microsphere modulates the cell cycle profile of encapsulated cells. Soft Matter 2013, 9, 4628-4634. [CrossRef]

178. Kulkarni, C.V.; Vishwapathi, V.K.; Quarshie, A.; Moinuddin, Z.; Page, J.; Kendrekar, P.; Mashele, S.S. Self-Assembled Lipid Cubic Phase and Cubosomes for the Delivery of Aspirin as a Model Drug. Langmuir 2017, 33, 9907-9915. [CrossRef]

179. Nilsson, C.; Edwards, K.; Eriksson, J.; Larsen, S.W.; Østergaard, J.; Larsen, C.; Urtti, A.; Yaghmur, A. Characterization of oil-free and oil-loaded liquid-crystalline particles stabilized by negatively charged stabilizer citrem. Langmuir 2012, 28, 11755-11766. [CrossRef]

180. Yaghmur, A.; Mu, H. Recent advances in drug delivery applications of cubosomes, hexosomes, and solid lipid nanoparticles. Acta Pharm. Sin. B 2021, 11, 871-885. [CrossRef]

181. Alinejad, Y.; Bitar, C.M.E.; Martinez Villegas, K.; Perignon, S.; Hoesli, C.A.; Lerouge, S. Chitosan Microbeads Produced by One-Step Scalable Stirred Emulsification: A Promising Process for Cell Therapy Applications. ACS Biomater. Sci. Eng. 2020, 6, 288-297. [CrossRef]

182. Geraili, A.; Xing, M.; Mequanint, K. Design and fabrication of drug-delivery systems toward adjustable release profiles for personalized treatment. View 2021, 2, 20200126. [CrossRef]

183. Selin, V.; Ankner, J.F.; Sukhishvili, S.A. Ionically Paired Layer-by-Layer Hydrogels: Water and Polyelectrolyte Uptake Controlled by Deposition Time. Gels 2018, 4, 7. [CrossRef]

184. Hsu, B.B.; Park, M.H.; Hagerman, S.R.; Hammond, P.T. Multimonth controlled small molecule release from biodegradable thin films. Proc. Natl. Acad. Sci. USA 2014, 111, 12175-12180. [CrossRef] [PubMed]

185. Pérez-Anes, A.; Gargouri, M.; Laure, W.; Van Den Berghe, H.; Courcot, E.; Sobocinski, J.; Tabary, N.; Chai, F.; Blach, J.F.; Addad, A.; et al. Bioinspired Titanium Drug Eluting Platforms Based on a Poly- $\beta$-cyclodextrin-Chitosan Layer-by-Layer SelfAssembly Targeting Infections. ACS Appl. Mater. Interfaces 2015, 7, 12882-12893. [CrossRef]

186. Guo, X.; Carter, M.C.D.; Appadoo, V.; Lynn, D.M. Tunable and Selective Degradation of Amine-Reactive Multilayers in Acidic Media. Biomacromolecules 2019, 20, 3464-3474. [CrossRef] [PubMed]

187. Min, J.; Choi, K.Y.; Dreaden, E.C.; Padera, R.F.; Braatz, R.D.; Spector, M.; Hammond, P.T. Designer Dual Therapy Nanolayered Implant Coatings Eradicate Biofilms and Accelerate Bone Tissue Repair. ACS Nano 2016, 10, 4441-4450. [CrossRef] [PubMed]

188. Min, J.; Braatz, R.D.; Hammond, P.T. Tunable staged release of therapeutics from layer-by-layer coatings with clay interlayer barrier. Biomaterials 2014, 35, 2507-2517. [CrossRef] [PubMed]

189. Ahmadi, S.; Rabiee, N.; Bagherzadeh, M.; Elmi, F.; Fatahi, Y.; Farjadian, F.; Baheiraei, N.; Nasseri, B.; Rabiee, M.; Dastjerd, N.T.; et al. Stimulus-Responsive Sequential Release Systems for Drug and Gene Delivery. Nano Today $2020,34$. [CrossRef]

190. Wang, B.; Liu, H.; Wang, Z.; Shi, S.; Nan, K.; Xu, Q.; Ye, Z.; Chen, H. A self-defensive antibacterial coating acting through the bacteria-triggered release of a hydrophobic antibiotic from layer-by-layer films. J. Mater. Chem. B 2017, 5, 1498-1506. [CrossRef] 
191. Tao, B.; Deng, Y.; Song, L.; Ma, W.; Qian, Y.; Lin, C.; Yuan, Z.; Lu, L.; Chen, M.; Yang, X.; et al. BMP2-loaded titania nanotubes coating with $\mathrm{pH}$-responsive multilayers for bacterial infections inhibition and osteogenic activity improvement. Colloids Surf. $B$ Biointerfaces 2019, 177, 242-252. [CrossRef]

192. Nam, K.; Kim, T.; Kim, Y.M.; Yang, K.; Choe, D.; Mensah, L.B.; Choi, K.Y.; Roh, Y.H. Size-controlled synthesis of polymerized DNA nanoparticles for targeted anticancer drug delivery. Chem. Commun. 2019, 55, 4905-4908. [CrossRef]

193. Choi, K.Y.; Correa, S.; Min, J.; Li, J.; Roy, S.; Laccetti, K.H.; Dreaden, E.; Kong, S.; Heo, R.; Roh, Y.H.; et al. Binary Targeting of siRNA to Hematologic Cancer Cells In Vivo using Layer-by-Layer Nanoparticles. Adv. Funct. Mater. 2019, 29. [CrossRef]

194. Yuan, W.; Li, C.M. Exponentially growing layer-by-layer assembly to fabricate $\mathrm{pH}$-responsive hierarchical nanoporous polymeric film and its superior controlled release performance. Chem. Commun. 2010, 46, 9161-9163. [CrossRef] [PubMed]

195. Zhao, X.; Liu, P. pH-sensitive fluorescent hepatocyte-targeting multilayer polyelectrolyte hollow microspheres as a smart drug delivery system. Mol. Pharm. 2014, 11, 1599-1610. [CrossRef] [PubMed]

196. Zhang, S.; Xing, M.; Li, B. Capsule-Integrated Polypeptide Multilayer Films for Effective pH-Responsive Multiple Drug CoDelivery. ACS Appl. Mater. Interfaces 2018, 10, 44267-44278. [CrossRef] [PubMed]

197. Zhang, S.; Zhou, S.; Liu, H.; Xing, M.; Ding, B.; Li, B. Pinecone-Inspired Nanoarchitectured Smart Microcages Enable Nano/Microparticle Drug Delivery. Adv. Funct. Mater. 2020, 30, 2002434. [CrossRef]

198. Zhang, S.; Vaida, J.; Parenti, J.; Lindsey, B.A.; Xing, M.; Li, B. Programmed Multidrug Delivery Based on Bio-Inspired CapsuleIntegrated Nanocoatings for Infected Bone Defect Treatment. ACS Appl. Mater. Interfaces 2021, 13, 12454-12462. [CrossRef]

199. Dubas, S.T.; Schlenoff, J.B. Swelling and Smoothing of Polyelectrolyte Multilayers by Salt. Langmuir 2001, 17, 7725-7727. [CrossRef]

200. Pethes, I.; Bakó, I.; Pusztai, L. Chloride ions as integral parts of hydrogen bonded networks in aqueous salt solutions: The appearance of solvent separated anion pairs. Phys. Chem. Chem. Phys. 2020, 22, 11038-11044. [CrossRef]

201. Lvov, Y.; Caruso, F. Biocolloids with ordered urease multilayer shells as enzymatic reactors. Anal. Chem. 2001, 73, 4212-4217. [CrossRef]

202. Lvov, Y.; Antipov, A.A.; Mamedov, A.; Möhwald, H.; Sukhorukov, G.B. Urease Encapsulation in Nanoorganized Microshells. Nano Lett. 2001, 1, 125-128. [CrossRef]

203. Woo, J.; Na, Y.; Choi, W.I.; Kim, S.; Kim, J.; Hong, J.; Sung, D. Functional ferrocene polymer multilayer coatings for implantable medical devices: Biocompatible, antifouling, and ROS-sensitive controlled release of therapeutic drugs. Acta Biomater. 2021, 125, 242-252. [CrossRef] [PubMed]

204. Yan, Y.; Johnston, A.P.; Dodds, S.J.; Kamphuis, M.M.; Ferguson, C.; Parton, R.G.; Nice, E.C.; Heath, J.K.; Caruso, F. Uptake and intracellular fate of disulfide-bonded polymer hydrogel capsules for Doxorubicin delivery to colorectal cancer cells. ACS Nano 2010, 4, 2928-2936. [CrossRef]

205. Wang, Y.; Wang, Q.; Feng, W.; Yuan, Q.; Qi, X.; Chen, S.; Yao, P.; Dai, Q.; Xia, P.; Zhang, D.; et al. Folic acid-modified ROSresponsive nanoparticles encapsulating luteolin for targeted breast cancer treatment. Drug Deliv. 2021, 28, 1695-1708. [CrossRef] [PubMed]

206. Seras-Franzoso, J.; Sánchez-Chardi, A.; Garcia-Fruitós, E.; Vázquez, E.; Villaverde, A. Cellular uptake and intracellular fate of protein releasing bacterial amyloids in mammalian cells. Soft Matter 2016, 12, 3451-3460. [CrossRef]

207. Zelikin, A.N. Drug releasing polymer thin films: New era of surface-mediated drug delivery. ACS Nano 2010, 4, 2494-2509. [CrossRef] [PubMed]

208. Thierry, B.; Kujawa, P.; Tkaczyk, C.; Winnik, F.M.; Bilodeau, L.; Tabrizian, M. Delivery platform for hydrophobic drugs: Prodrug approach combined with self-assembled multilayers. J. Am. Chem. Soc. 2005, 127, 1626-1627. [CrossRef] [PubMed]

209. Orozco, V.H.; Kozlovskaya, V.; Kharlampieva, E.; López, B.L.; Tsukruk, V.V. Biodegradable self-reporting nanocomposite films of poly(lactic acid) nanoparticles engineered by layer-by-layer assembly. Polymer 2010, 51, 4127-4139. [CrossRef]

210. Boi, S.; Dellacasa, E.; Bianchini, P.; Petrini, P.; Pastorino, L.; Monticelli, O. Encapsulated functionalized stereocomplex PLA particles: An effective system to support mucolytic enzymes. Colloids Surf. B Biointerfaces 2019, 179, 190-198. [CrossRef]

211. Ham, T.R.; Farrag, M.; Leipzig, N.D. Covalent growth factor tethering to direct neural stem cell differentiation and selforganization. Acta Biomater. 2017, 53, 140-151. [CrossRef]

212. Sieving, P.A.; Caruso, R.C.; Tao, W.; Coleman, H.R.; Thompson, D.J.; Fullmer, K.R.; Bush, R.A. Ciliary neurotrophic factor (CNTF) for human retinal degeneration: Phase I trial of CNTF delivered by encapsulated cell intraocular implants. Proc. Natl. Acad. Sci. USA 2006, 103, 3896-3901. [CrossRef]

213. Borlongan, C.V.; Thanos, C.G.; Skinner, S.J.; Geaney, M.; Emerich, D.F. Transplants of encapsulated rat choroid plexus cells exert neuroprotection in a rodent model of Huntington's disease. Cell Transplant. 2007, 16, 987-992. [CrossRef] [PubMed]

214. Emerich, D.F.; Orive, G.; Thanos, C.; Tornoe, J.; Wahlberg, L.U. Encapsulated cell therapy for neurodegenerative diseases: From promise to product. Adv. Drug Deliv. Rev. 2014, 67, 131-141. [CrossRef] [PubMed]

215. Kauper, K.; McGovern, C.; Sherman, S.; Heatherton, P.; Rapoza, R.; Stabila, P.; Dean, B.; Lee, A.; Borges, S.; Bouchard, B. Two-Year Intraocular Delivery of Ciliary Neurotrophic Factor by Encapsulated Cell Technology Implants in Patients with Chronic Retinal Degenerative DiseasesIntraocular Delivery of CNTF via ECT. Invest. Ophthalmol. Vis. Sci. 2012, 53, 7484-7491. [CrossRef] [PubMed] 
216. Eriksdotter-Jönhagen, M.; Linderoth, B.; Lind, G.; Aladellie, L.; Almkvist, O.; Andreasen, N.; Blennow, K.; Bogdanovic, N.; Jelic, V.; Kadir, A. Encapsulated cell biodelivery of nerve growth factor to the basal forebrain in patients with Alzheimer's disease. Dement. Geriatr. Cogn. Disord. 2012, 33, 18-28. [CrossRef]

217. Perez-Bouza, A.; Di Santo, S.; Seiler, S.; Meyer, M.; Andereggen, L.; Huber, A.; Guzman, R.; Widmer, H.R. Simultaneous Transplantation of Fetal Ventral Mesencephalic Tissue and Encapsulated Genetically Modified Cells Releasing GDNF in a Hemi-Parkinsonian Rat Model of Parkinson's Disease. Cell Transplant. 2017, 26, 1572-1581. [CrossRef] 